\title{
Politics and the Work of the Dead in Modern India
}

\author{
CHRIS MOFFAT
}

School of History, Queen Mary University of London

Published in Comparative Studies in Society and History 60:1 (2018), pp.178-211.

\section{A REVOLUTIONARY INHERITANCE}

This article is concerned with the conceptual and methodological problem of "afterlives" in history. Its story unfolds on the terrain of twentieth- and twenty-first-century India, but it aims to carve a place for the unquiet dead in the history of political thought more generallyto interrogate what the demands of inheritance might mean for politics in a given present. "Inheritance" is understood here not as a logic of succession but as an untimely interference, a call to responsibility from that which is not present, whose corporeal existence has been extinguished. Rather than approaching "afterlives" simply as the willful conjuring of the dead by the living, this article takes seriously the force of the dead as entities to whom something is owed, and who might themselves conjure politics, holding the living to account. 
Entering this problem-space does not require an admission that ghosts actually "exist"; there are no disembodied voices or revenant spirits at work in the discussion that follows. The possibility of being "haunted" is, however, accepted as something more than metaphor, superstition, or individual psychosis. It is approached as what Avery Gordon calls an "experiential modality," a way of knowing and feeling the world, and more than this a "constituent element of modern social life," the underside of historicism's forward march through time, wherein the compulsion toward the future becomes simultaneously the constant iteration of a loss. ${ }^{1}$ Haunting is where something "supposedly over and done with" makes itself known. ${ }^{2}$ This experience can be contrasted with what Dipesh Chakrabarty has called a "decisionist" approach to the past, embodied in the confident modern who stands in an emancipated present, drawing tactically from the past but in no way bound to it. ${ }^{3}$ To be haunted is to feel this progression falter. It suggests we are not always in charge of our relationship to the past and that the past, instead, may have designs on the present.

The language of haunting has proved fruitful for critiquing paradigms of foundation, presentism, and teleology in Western academic work since the 1990s, fueling the development of trauma studies, ${ }^{4}$ facilitating queer interrogations of "chrononormativity,", and prompting a debate on the charge of left politics after the Cold War, signaled famously

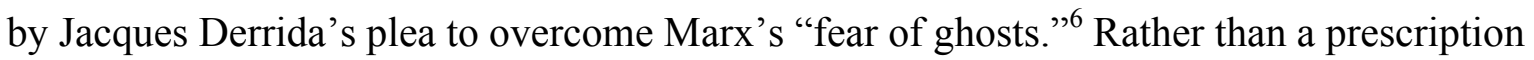
for learning to live with ghosts, as was Derrida's ethical injunction, I am concerned with the cajoling, interruptive potential of the dead in contemporary politics - the manner in which heroes or victims from the past are accepted as having a stake in ongoing political struggles and indeed are seen to demand action in the present. For this reason, the figure of the martyred revolutionary appears of particular interest, since here the question of "afterlives" becomes entangled with the call to complete a revolution left "unfinished," to secure a freedom not yet won. 
Focusing its discussion on India's recent history, this article echoes Chakrabarty's insistence that any discussion of the modern political subject in this context must coincide with a critique of the nature of historical time. ${ }^{7}$ But whereas Chakrabarty's interest in the untimely is primarily via the persistence of non-historicist orders of temporality in modern India - the enchanted worlds of gods and spirits - my concern is with what is clearly a malady of historicism, something that is supposed to be "past" but continues to make itself known: "endings that are not over," in Gordon's provocative phrase. ${ }^{8}$ The argument that dead revolutionaries can function as more than honored antecedents and in fact appear as active interlocutors in ongoing political struggles is thus not restricted to India. Attention to the force of inheritance and its call to responsibility will resonate with debates across the postcolonial world, where the collapse of anticolonial utopias and the compromises of postindependence states remain the subjects of widespread lament. ${ }^{9}$ Radical figures from the past, from James Connolly to Stephen Biko, ${ }^{10}$ weigh upon the present in their diverse contexts as reminders of paths not taken, of potential unfulfilled, even as "official" hagiographers and state authorities labor to absorb them into a consensus national pantheon. This tension between the dead radical's potential to incite and the desire among state institutions for containment characterizes the multifarious afterlives of the figure traced in this essay: the Indian revolutionary martyr Bhagat Singh (1907-1931). His potency as a reminder of "unfinished business" is sharpened by the fact of his young death-executed by colonial authorities at age twenty-three - and reinforced in the Indian context by the consonance of his celebrated self-sacrifice with a rich tradition of imagining heroic death and its aftermath. ${ }^{11}$ Born in 1907, Bhagat Singh's brief but eventful life as a revolutionary organizer, Bolshevik sympathizer, and critic of Gandhi ended in March 1931 when he was hanged for killing a British police officer in Lahore and bombing the colonial Legislative Assembly in New Delhi. ${ }^{12}$ Today, eighty-seve years later, he is recalled as shaheed-e-azam, "the great 
martyr." Dislocated from the partisan political milieu of 1920s India, Bhagat Singh appears as an injunction to stand against tyrants - to never compromise, never surrender, even in the face of death. Allegiances are declared across the political spectrum, from the nationalist right to the Maoist left, Sikh militants to environmentalist youth groups, the Army in India to pacifists in Pakistan. Researchers have, for the most part, approached this ideological promiscuity as a prompt to uncover who Bhagat Singh "really" was, what he "really" fought and died for, dismissing his spectral wanderings in search of the corpse, immobile and amenable to excavation. ${ }^{13}$ But to dismiss these afterlives simply as "incorrect" invocations is to elide the important insights they provide regarding the complicated legacies of political violence in contemporary India and the ongoing ambivalence toward the independence moment and the "freedom" it is seen to represent.

This article is concerned precisely with Bhagat Singh's apprehension as the spectral "third person" in the political argument of modern India. I take some liberty, here, with the "third person" conceptualized by Jacques Rancière in his discussion of modern political dialogue. For Rancière, it is the grammatical third person — the "they"-which exceeds and breaks the simple rationality of a dialogue of interests; that is, the communication between first and second person, the "I" and the "you," freighted with individual motivations and value systems. The third person marks the multiplication of persons that creates a community; as when the workers' representative declares the "workers will not accept" a particular settlement. It places a dispute in common. ${ }^{14}$ My use of "third person" combines this third person address (an appeal to the "they") with the force of the dead man's gaze. It resonates thus with Émile Benveniste's illuminating discussion of the third person as a "nonperson," following the Arabic grammarian's al-ya 'ibu: "the one who is absent."15 These converge to capture a vision of community that spans the living and the dead, establishing a dispute that is held in common across sequential time. Such a rendering allows us to 
understand a figure like Bhagat Singh as more than just an object willfully wielded, but rather as an integral identification: a comrade with whom a common predicament is shared. This is what is meant by the "work" of the dead: the manner in which the demands of inheritance distract, deter, or cajole the living, who articulate a sense of responsibility to figures no longer present and affirm their stake in a struggle caught "halfway."

\section{ON BEING HALFWAY}

I borrow this notion of being caught "halfway" from Mridula Garg's 1980 novel Anitya, in which her protagonist Avijit Bansal finds himself haunted by the specter of Bhagat Singh. A student activist during the anticolonial struggle, Avijit is now a wealthy industrial manager in an independent India of the 1950s; he wears uncomfortably the title of "freedom fighter," keenly aware that the revolution he once passionately desired never happened. Though the British have left, "nothing has changed." "16 Garg, one of India’s foremost Hindi novelists, interrogates in Avijit a generation's experience of the independence moment: that abrupt transition from the urgency of anticolonial mass movement to the hushed reality and pragmatic demands of governance in a postcolonial polity. Garg was only nine years old when Jawaharlal Nehru raised the flag of an independent India over Delhi's Red Fort on 15 August 1947, but she recalls the moment within her politicized Calcutta family as one characterized by "disillusionment, angst, frustration and guilt" rather than triumph. This Independence, she records in an author's note, "was nothing more than a transfer of power. At best we could say we had reached halfway to freedom. Or was it halfway to nowhere?"17

Avijit's struggle with India's imperfect azaadi (freedom), where the class, caste, and gender inequalities of colonial society persist, is experienced as highly personal. His own compromises are rendered explicit by juxtaposition with the self-sacrificing revolutionary, 
whether his comrades tortured in jail in the 1940s, or Bhagat Singh himself. Fragments from the martyr's corpus interrupt Garg's narrative, throwing Avijit out of postcolonial quietude back into the critical exigency of anticolonial struggle, falling in dream-like lapses from his 1950s corporate office to the hopeful solidarity of 1930s student meetings. When he meets Kajal, an old comrade still committed to revolutionary struggle, it is as if her very person transmits another time. "What do you want to do, Kajal?" Avijit asks. "I want to complete what was left half done," she replies. ${ }^{18}$

The demands of "unfinished business" condition Bhagat Singh's reception in the postcolonial present as a demanding and indeed necessary interlocutor, contesting a vision that treats the 1947 independence moment as foundational, the beginning of a new sequence and the end of an old. The following sections illuminate Bhagat Singh's capacity to incite political struggle through three different experiences of a present "halfway." The first is the experience of repetition and relapse — of being caught halfway again - and here I am interested in debates around corruption in twenty-first-century Indian politics. The second considers the problem of duration — of being halfway still — fighting for a revolution that is yet to come. Finally, the predicament of being halfway always: the trans-historical significance of Bhagat Singh's opposition to tyranny. These experiences are differentiated for the purpose of discussion but can and do overlap, as we shall see. As stutters, delays, and diversions complicating the forward march of time, each underlines the essay's approach to "afterlives" as a malady of (rather than departure from) historicism.

In drawing together these three experiences of a present "halfway"-repeated, endured, or perpetual — the object is not to prove commensurability between the different political projects they provoke. Certainly, the Hindu nationalist vigilantes discussed in Section III would balk at proximity to the Maoist student groups in Section IV or the Sikh separatists in Section $\mathrm{V}$, and vice versa for each. But comparison allows an important point to be made 
about Bhagat Singh's role as spectral “third person” in twenty-first-century Indian politics. Though his heroic gestures and self-sacrificial militancy may exceed precise ideological meaning, their effects are not completely unbound. As I have argued elsewhere, Bhagat Singh's life and death stand demonstrative of a particular way of being in and toward a political present: specifically the value of courage, commitment, and a capacity for action. ${ }^{19}$ The revolutionary's projected response to a condition of unfinished business ("what does Bhagat Singh want?") is similarly interpreted in highly individuated practices and not through law, institutions, or even a precise program. Action sets the terms for fidelity to dead comrades, the form of a responsibility. Thus Garg's mix of personal anxiety with political collapse in the figure of Avijit is telling: the independence generation, she argues, "shied away from taking responsibility, and opted for status quo rather than revolutionary change., ${ }^{, 20}$ The three sections below explore the force of a revolutionary inheritance and its incitement to personal responsibility. Drawn primarily from periods of fieldwork in North India from 2011 to 2013, they reflect the characteristics of this conjuncture: the height of popular movements against government corruption, the rise of Bharatiya Janata Party (BJP) politician Narendra Modi as "outsider" to national politics, and the global reverberations of rebellion stretching from Zuccotti Park to Tahrir Square. My central concern is with processes of contextualization, where political actors negotiate and come to terms with the present they stand and speak on, in league with the dead who cajole, demand, or simply keep watch. ${ }^{21}$

\section{ON “TRAITORS, ANTI-NATIONALS \& CORRUPTS”}

It is difficult to discuss the contemporary afterlives of Bhagat Singh without invoking the film Rang De Basanti, Bollywood star Aamir Khan's box office hit released on Republic Day, 26 January $2006 .{ }^{22}$ Promoted with a revolutionary promise (“a generation awakens”) 
and feted by the Indian media for making nationalism seem "exciting" again, ${ }^{23}$ the film has been retrospectively inducted into a genealogy of the "India Against Corruption" (IAC) movement, a nation-wide agitation inaugurated five years later in 2011 and centered around the demand for a Lokpal ("ombudsman") to tackle corruption in government. Indeed, the final scenes of Rang De Basanti (hereafter $R D B$ ) appear to the post-2011 viewer as an uncanny vision of things to come: crowds of youth in Delhi speak excitedly to news cameras about their desperate urge to change India's political system, describing "a fire ignited in our minds and hearts." A young woman tells the reporter, "Agar hamare har insan ko jagna hai to aisa hi koi dhamak hamare desh ko zarurat hai" (An explosion like this is necessary if we are to stir every Indian [out of their slumber]).

$R D B$, which depicts the political awakening of a group of young men in twenty-firstcentury urban India, is first and foremost a story of patricide, of a generation brought to kill its corrupt parents. As several critics have noted, the film reflects a middle-class "fantasy" about corruption in India, with individual greed presented as the central cause of national stagnation and the primary barrier to India's "world class" status. This rot is taken to demand internal purification: a cleansing of structures rather than any change in the structures themselves. ${ }^{24}$ It is significant that $R D B$ was released at the height of market liberalism in India, with economic reforms initiated in 1991 reaching their apogee in record GDP growth rates (9 percent in 2007) and Manmohan Singh, the finance minister who oversaw these structural changes, newly elected to the prime minister's office. The film communicates the populist mirror of this process of liberalization: a growing frustration with the bureaucratic inertia and the belief that political graft was preventing the country from reaching its "full" potential. In $R D B$, as in the IAC movement inaugurated in 2011, it is urban, educated youth who form the enthusiastic vanguard for the process of political (as opposed to consciously "ethnic" or "religious") purification and mobilize to pressure a stubborn system from outside. 
Bhagat Singh and his comrades in the Hindustan Socialist Republican Association (HSRA) are directly implicated in the political awakening depicted by $R D B$. The tangled temporal experience evoked by Garg's Anitya is also an explicit feature of the film, with scenes from twenty-first-century Delhi collapsing into sepia-soaked episodes from interwar India. This device is enabled, in part, by the film's premise, wherein a group of partyoriented, politically-apathetic students are talked into performing in a film about the anticolonial revolutionaries, so that they end up directly acting out this history. But these are more than just flashbacks, and the postcolonial present is revealed to be a mirror of the past, stricken with the same problems Bhagat Singh fought in his own time. It is through this sense of repetition, of the return of a battle that was supposed to be finished, that the protagonists come to greet Bhagat Singh as an interlocutor in their present.

When Ajay, a close friend of the group and a patriotic Air Force pilot, dies due to a malfunctioning aircraft, the distance between past and present collapses and the return to a point "halfway" affirmed. In a vision of the infamous Amritsar massacre at Jallianwala Bagh in 1919, the British General Reginald Dyer orders his troops to shoot down innocent Indians before he transforms into the corrupt, twenty-first-century Indian defense minister who procured damaged airplanes and is thus blamed for Ajay's death. The pilot himself then appears in the Bagh in the line of fire. As the characters gather to mourn Ajay's death, they flicker in conversation between themselves and the HSRA revolutionaries, so that a decision to assassinate the defense minister appears to be made by Bhagat Singh himself. The subsequent killing is shown interspersed with Bhagat Singh's shooting of Assistant Police Superintendent J. P. Saunders in Lahore in December 1928, the "outrage" for which he was later executed. In the film's climax, the students-turned-vigilantes are ambushed by heavily armed police in central Delhi. Dying from bullet wounds, the men look up to see ghosts of the revolutionaries standing over them, smiling as if to affirm their sacrifice. In one shot, 
Aamir Khan's character laughs defiantly in split-screen with his ghostly mirror, the revolutionary Chandrashekhar Azad, who was himself killed in a police shootout in February 1931.

Unlike Garg's Anitya, $R D B$ is optimistic about the independence moment and the freedom it represents. Patriotic values are enshrined, however, in individuals and not in state institutions: the pilot Ajay, clearly, but also his mother, who nourishes in her son an idea of service even if the military has already cost her a husband. Both these characters are betrayed by the insatiable self-interest of politicians. The specter of Bhagat Singh looms over this dispute as an icon of integrity, legitimating an appeal to justice that exceeds the law.

The IAC movement which swelled under the leadership of veteran social activist Kisan "Anna" Hazare in 2011 negotiated a similar blurring of presents in its call for a national Lokpal, not least in the positioning of Hazare under the shadow of M. K. Gandhi, whose image was omnipresent in rallies and meetings. While Gandhi provided the model of action - the fast-to-death, the prayer, the ethical regime (vegetarianism, celibacy, teetotalism, etc. $)^{25}$-it was the sacrifice of the revolutionary martyrs that Indians were urged to vindicate: it was the profound commitment of Bhagat Singh and his comrades that needed to be repeated. This idea of a terrain shared with the anticolonial dead was cultivated by Hazare's routine insistence that Indian youth accept that they are part of a "second freedom struggle." Once, long ago, independence was declared but, in Hazare's words, "today we cannot experience independence": "What independence? Corruption, loot is still here. Only goras ['whites'] left and kalas ['blacks'] come in, that is the only difference.... This government is intoxicated by power and money. It cannot see anything else. They have forgotten the sacrifices by the likes of Bhagat Singh, Sukhdev and Rajguru. Like a drunk man becomes unconscious, similarly the government is unconscious. ${ }^{26}$ In this insistence on an anticolonial problematic on the terrain of the present, a stain in sepia is effected. The call to unfinished 
business is revealed by the untimely slogan inscribed on a Gandhi cap: mujhe chahie swaraj (I want self-rule). When police batons break up a Delhi rally against kala dhan (black money $^{27}$ ), a furious Hazare compares the event directly to Jallianwala Bagh, albeit without the gunfire, and asks, "What is the difference between your democracy and the British Raj?"28

Bhagat Singh is admitted into the political argument here not simply as a model of commitment - “till we sacrifice, we won't get the right independence," Hazare told his followers in $2011^{29}$ - but also as a figure to whom the living are accountable. To fail to act is to betray Bhagat Singh. Thus Hazare finds it appropriate to apologize to the famous martyr and his two comrades, also hanged, on their 2013 death anniversary: "Bhagat Singh, Sukhdev, Rajguru. Thank you. Sorry for what we've done with the freedom you won for us." ${ }^{30}$ This is a rhetorical gesture, certainly, but the form of address to "contemporaries" affirms the untimely stakes of the IAC's political dispute. If the problems faced by the revolutionaries have returned, so too must their courage be repeated. "Many people will have to go to jail again, be lathi-charged ... that time is here now," Hazare affirmed in $2011 .^{31}$ "The leaders have become traitors.",32

Hazare's constant appeal to a community of the dead sets conditions for individual conduct, drawing the traditionally opposed Gandhi and Bhagat Singh together in a demand for self-sacrifice. When the Maharashtra state government offers Hazare security protection in recognition of his rising political status, the activist rejects the offer, telling the press "I don't want security," "if [Bhagat Singh and Rajguru] did not fear for life during their fight for freedom, why should I fear?"33 Around the same time, Hazare tells his supporters that he does not fear death "because I have not forgotten Bhagat Singh, Rajguru and Sukhdev.... I will prefer to embrace death in the service of nation to dying from heart attack.",34 Admissions of a shared predicament are echoed by his supporters. As one participant in 
Hazare's April 2011 fast explained to the Deccan Herald, he had read about the Lahore martyrs in school, but "it was only now they rang true." ${ }^{35}$ Another young man in Nagpur joined Hazare's August 2011 hunger-strike in solidarity: "When there were weak moments, I would recall patriots like Bhagat Singh and Chandrashekhar Azad. Their sacrifices made mine seem so small in comparison." ${ }^{36}$ The HSRA slogan Inquilab Zindabad [“Long Live Revolution"] resonated through Delhi in 2011, particularly at Ramlila Maidan, where celebrity yoga guru Baba Ramdev inaugurated a protest in June for the repatriation of kala dhan, opening the fast by garlanding statues of Bhagat Singh, Rajguru, and Sukhdev at a nearby Delhi park. ${ }^{37}$

Ramdev's influence on the IAC is important to note here, signifying the movement's entanglement with conservative Hindu voices in India. The IAC's argument for national integrity has been frequently criticized for its majoritarian overtones, seen to attract supporters like Ramdev whilst alienating Muslim supporters and leftist groups in the country. ${ }^{38}$ But the IAC has also been criticized by right-wing voices for not going far enough in its offensive against internal enemies. It is with this in mind that I want to discuss a small Delhi-based outfit that emerged in conversation with the Hazare mobilizations, but ultimately departed from them: the Bhagat Singh Kranti Sena (Revolutionary Army, hereafter BSKS), founded in $2011 .{ }^{39}$

Although the BSKS echo Hazare in demanding action against India's corrupt eldersfigured consistently as the "establishment" Congress party—-the organization acknowledges Bhagat Singh's stake in the present not to supplement a Gandhian notion of self-sacrifice, but rather to assert its limitations. It affirms that this "second freedom struggle" might demand a militant responsibility that departs from the strictures of nonviolence. The Sena's endorsement of a muscular brand of national assertion is more consistent with critiques of "effeminate" nonviolence theorized by early twentieth-century Hindutva ideologues like K. 
B. Hedgewar, ${ }^{40}$ and in fact BSKS president and founder Tajinder Pal Singh Bagga has a history of involvement with right-wing youth organizations. Other members have been linked to the ultra-conservative Sri Ram Sena, infamous in India for their acts of vigilante moral policing. The group's connection to Hazare and the IAC can thus only be seen as ambivalent, and as we will see, it turns toxic with regard to Hazare's ally, the activist lawyer Prashant Bhushan.

The object of the BSKS is reflected in an early online manifesto: this "team of guys who are crazy for nation" emphasize the need to fight "the traitors inside the nation [who are] killing us.... those who are trying to divide my nation from Kashmir to Arunachal." ${ }^{\text {41 }}$ Images of a muscular Bhagat Singh are reproduced on posters and social media sites, his gaze demanding vigilance against "traitors, anti-nationals \& corrupts," enemies responsible for the country's return to a point halfway. The organization announced itself on the national stage with a physical attack on Prashant Bhushan in his Supreme Court offices in October 2011. The lawyer was confronted by three of the group, including twenty-four-year-old Bagga, after publicly suggesting the need for an independence referendum in the Indian state of Jammu and Kashmir and endorsing the possible removal of the Armed Forces Special Powers Act from the Kashmir Valley. ${ }^{42}$ Support for such measures remains highly contentious in India, where Kashmir is consecrated in the nationalist imaginary through ideas of territorial integrity and by the blood spilled in the region by Indian soldiers across decades of conflict. ${ }^{43}$ The subsequent beating of a startled Bhushan was captured, conveniently, by TimesNow television cameras present on scene. Bagga, who was not charged with the incident, explained the gesture later on social media: "He try $[\mathrm{sic}]$ to break my nation, I try to break his head." 44

In the Bhushan attack we see how the Sena seeks to honor Bhagat Singh's sacrifice not simply by affirming the principle of an independent and territorially integrated nation-state, 
for which support of the Indian army is central, but also by promoting a spirit of extralegality toward this end. The group's vigilante ethic appears explicit in an image posted to its Facebook page in August 2011 in which Bhagat Singh's head appears on a muscular body, striding forward menacingly and wielding a wooden plank (see image 1).

I met Bagga and the Sena's General Secretary Vishnu Gupta in December 2011, shortly after the Bhushan attack, at the Indian Coffee House in Delhi's Connaught Place. Bagga insisted during our conversation that the ideology of Bhagat Singh must be understood as desh bhakti (nationalism, lit. "devotion to the nation"), and that because of this he remains an important model for Indian youth. If there is any element of Bhagat Singh's writings that the BSKS engage with, it may be the simple invocation, "It takes a loud voice to make the deaf hear," a phrase the revolutionary himself borrowed from French anarchist Auguste Vaillant, hanged in 1893 for bombing the Chamber of Deputies in Paris. ${ }^{45}$ The formulation appears tangled with Bagga's own slogan on Sena posters (see image 2). But the resonance of text pales in comparison to the thrill attached to the reenactment of revolutionary tropes: when we met, Bagga had recently spent a few days in Tihar Jail, Delhi, arrested while protesting censorship outside then-Communications Minister Kapil Sibal's home. This experience of prison he wore as a badge of honor, a mark of his patriotic commitment. ${ }^{46}$

Despite this call to repetition, there is an interesting inversion in the Sena's engagement with Bhagat Singh, as Simona Sawhney has noted, and that is their disavowal of martyrdom. The aforementioned manifesto invokes a history of invaders, suggesting, "We are dying frm [sic] last 1000 years," but "Now we will not die, if we will die, then who will give right treatment to the traitors \& anti-nationals." Rather than suffering violence, the Sena wish to distribute it. Sawhney suggests that the group's citation of the 1920s revolutionary Ram Prasad Bismil's poem Sarfaroshi ki Tamanna (The desire to trade one's head) in their manifesto must be read with this in mind, especially the line that promises to "play holi with 


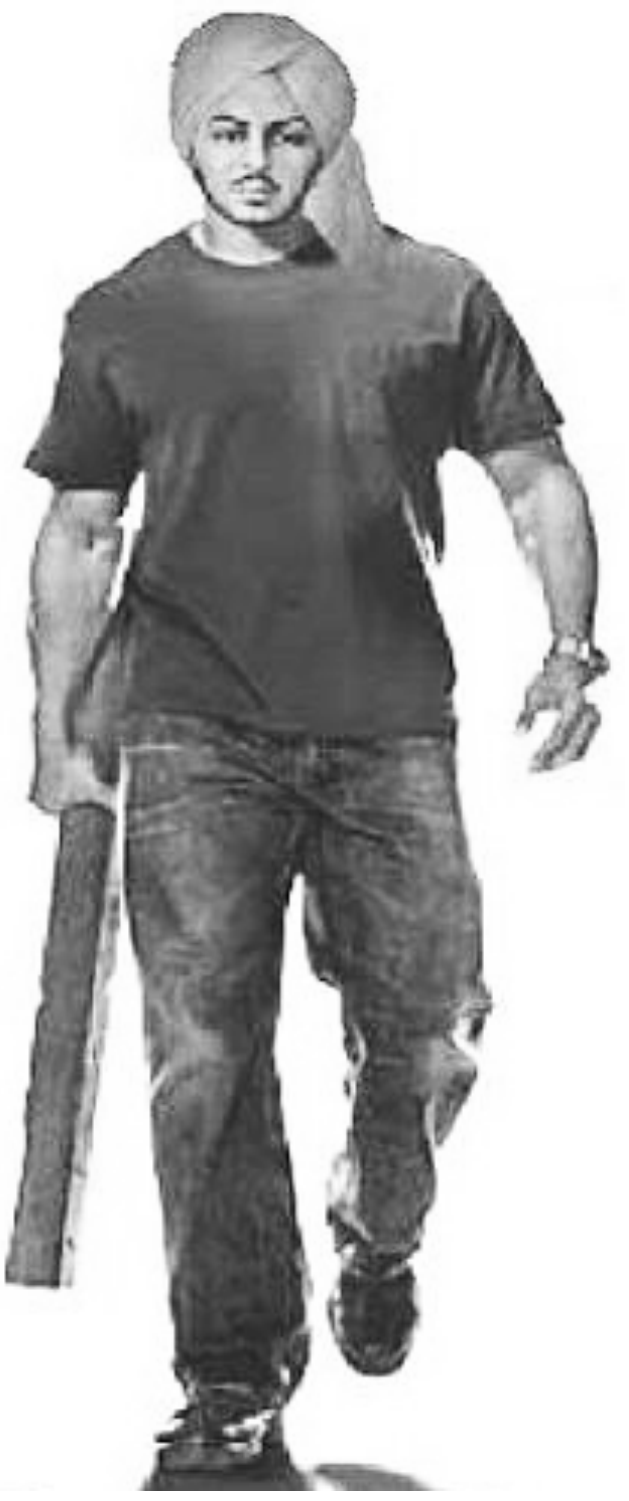

Image 1: Depiction of Bhagat Singh on BSKS FACEBOOK PAge (Posted 25 August 2011)

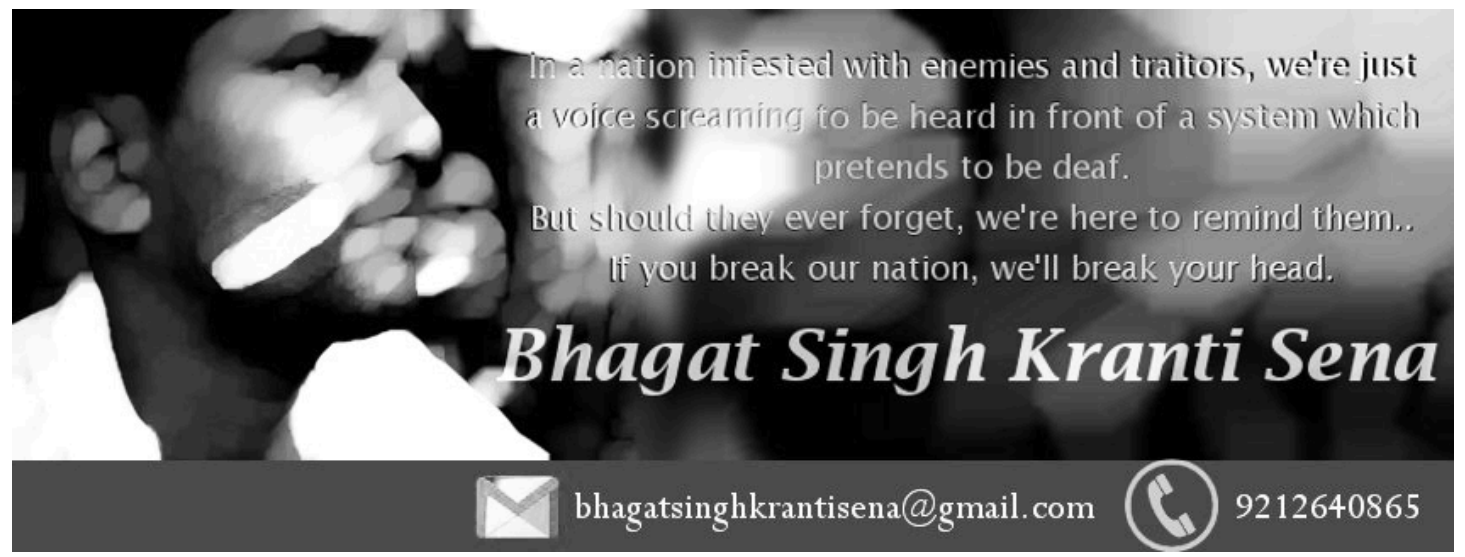

Image 2: Cover Image from BSKS FACEBOOK PAge (Posted 4 November 2011) 
blood when the nation is in peril." If, for Bhagat Singh and his comrades, this meant accepting that their own blood could be spilled alongside that of an enemy, for the Sena it is focused solely on the blood of another - the anti-national who must be eradicated. ${ }^{47}$

The BSKS has, since the Bhushan episode, coordinated a series of spectacles which, though disparate and at times contradictory, all have at their heart some idea of a corrupt or imperiled nation to be defended through individuated action. This nation necessarily exceeds existing institutions, and indeed, on Republic Day, 26 January 2012, members of the Sena gathered outside Jammu \& Kashmir House in Delhi to set alight the page of the Indian constitution that discusses special status for Kashmir. They have protested cultural events on Kashmir, for instance the screening of Sanjay Kak's documentary Jashn-e-Azadi at Delhi University in February 2012, and in March 2012 managed to steal the cap from separatist leader Syed Ali Shah Geelani outside that same institution. Advances against "corrupts" have included the leaking of a sex tape allegedly involving Rajya Sabha MP Abhishek Manu Singhvi, which caused the Congress leader to resign from the Parliament Standing Committee on Law and Justice. The Sena were especially active during the anti-rape protests that swept Delhi in December 2012, demanding the death penalty for rapists and offering self-defense training for women in yet another call to personal responsibility. ${ }^{48}$

In 2013, however, the BSKS transformed rapidly into a mouthpiece for then-aspiring BJP prime ministerial candidate Narendra Modi, accepting the convergence of their many aims - internal vigilance, muscular nationalism, and religious pride - in Modi's polarizing persona. Although Modi positioned himself as an outsider even within the BJP, the acceptance of Bhagat Singh as a part of a Hindu nationalist inheritance is not new to the right-wing party. In 1997, Bhagat Singh's image adorned the chariot steered by party president LK Advani across the country on his Swarna Jayanti Rath Yatra (Fiftieth Anniversary of Independence Pilgrimage), amidst a pantheon of nationalist "ideal men." ${ }^{49}$ In 
the build-up to national elections in 2014, Modi, who had been a key strategist for Advani's Yatras in the $1990 \mathrm{~s},{ }^{50}$ took the opportunity provided by the 23 March death anniversary to celebrate the Lahore martyrs on social media: 'Inspired by call of 'Inquilab Zindabad,' these revolutionaries preferred to face the gallows rather than bow to injustice. Salutes to them." Communist Party of India-Marxist (CPI-M) politburo member Sitaram Yechury saw in this gesture a conservative nationalist embrace of a left-wing icon, and condemned it as an "exercise in sheer duplicity." And yet Bhagat Singh's invocation here is more than a mere populist gesture, especially since Modi labors to position himself as someone who will not compromise his ideals and who - appearing as an outsider to the Indian political machine, the son of a tea-seller from Vadnagar-is critical of the traditionally dominant Congress Party's vision of what it means to be "national." I do not mean to suggest that Modi is particularly interested in Bhagat Singh, even if he continues to mark 23 March as prime minister, paying a visit to the National Martyrs Memorial in Hussainiwala in 2015. He has devoted considerably more resources to commemorating the border-crossing Indian revolutionary Shyamji Krishnavarma, as Harald Fischer-Tiné has shown. ${ }^{52}$ But this is nonetheless an important example of how a spectralized Bhagat Singh can sidestep historical contradictions, entering the political argument meaningfully as an uncompromising patriot whose model of commitment remains not only desirable, but which is also seen to demand action.

The agenda of purification mobilized variously by Modi, the BSKS, Hazare, and indeed by Hazare's former strategist Arvind Kejriwal—who founded his own Aam Admi ("Common Man”) Party (AAP) in November 2012 with similar “outsider" appeal—accepts Bhagat Singh as a worthy interlocutor on the pretext of a regression, a return to halfway. But these variant calls for a renewed freedom struggle, in which the "corrupt parents" of the postcolonial state must be eliminated, all encapsulate what the political scientist Saroj Giri calls the same tendency or "emerging rationality" of Indian politics: that of neoliberal capital. ${ }^{53}$ And so the 
unfinished business of Bhagat Singh's death is read, not as political and social revolution, but rather as the responsibility to ensure national "potential," which necessarily encompasses the flourishing of the market. The revolutionary's exemplary seizure of personal responsibility is calibrated to buttress a neoliberal rhetoric of individual action. Giri traces a shift in BJP and AAP rhetoric from the Congress' traditional social-democratic containment of the lower classes to a celebration of egalitarian opportunity and appeals to the "citizen-entrepreneur," rejecting pervasive structural inequalities like caste. Here, to the dismay of his leftist proponents, Bhagat Singh's work as the spectral "third person" is put to the service of an emergent neoliberal consensus; the sense of "something-to-be-done" that his presence exhorts is aligned with demands for the easy flow of capital.

Whatever the unity conjured by Hazare's rhetorical maneuver, the conventional (if problematic) $)^{54}$ differentiation between a "nonviolent" Gandhi and "violent" Bhagat Singh is ultimately exacerbated by this neoliberal conjuncture, as William Mazzarella demonstrates in his study of the Mahatma's meaning in post-liberalization India. In an environment characterized by consumerist emphasis on self-gratification and a Hindutva assertion of "aggressive virility," Gandhi's ascetic self-restraint is treated as increasingly "outmoded." Films like Rang De Basanti and other biopics of Bhagat Singh like Rajkumar Santoshi’s Legend of Bhagat Singh (2002) can be contextualized within a broader turn toward "a more macho figuring of national agency," joined in this process by militaristic patriot SC Bose and nationalist "Iron Man" Vallabhbhai Patel, other untimely figures thrust onto the terrain of the present. ${ }^{55}$ But just as there is always more than one inheritance, so too can Bhagat Singh's contrast with Gandhi be read differently. In Christopher Pinney's analysis, Bhagat Singh's popularity is again as a distinctly "modern" figure — muscular and masculine perhaps, but ultimately fluid and unpredictable, for whom no project of an autochthonous "ancestral" past plays a role. ${ }^{56}$ This vision of the revolutionary less as the embodiment of something "pure" 
and instead as an exhortation to dissident mobility is the focus of the next section.

IV. "FOR I NO LONGER END IN MYSELF”

In November 2011, the Chandigarh-based activist Gaurav Chhabra released a one-hour, "zero-budget" film called Inklab, shot in cinema verité style and inspired by the director's impressions of contemporary activist culture in India. ${ }^{57}$ Chhabra's interest in the decentralization of "citizen activism" through educational initiatives and transparency tools like Right to Information (RTI) legislation is reflected in the film's aesthetic. Shot with a camcorder, it refuses to reveal many faces and directs the viewer's gaze off-center. The film's two protagonists are thus overheard, debating the meaning of dissent in twenty-firstcentury India, as the lens focuses on a glass of chai, a shadow on the wall, a computer keyboard. Inklab, Chhabra's "laboratory of ideas," is deployed as a homophone for Inquilab. ${ }^{58}$

Bhagat Singh haunts Chhabra's film in a manner distinct from $R D B$. He is mentioned only once in passing, but the familiar image of a young revolutionary in trilby hat flashes up at important points: glimpsed on the cover of books scattered on a desk or stenciled with spray paint on a wall. In one scene, the camera dwells meaningfully on a sticker of the revolutionary placed on an auto-rickshaw window. But more powerful than these direct visual references is the way in which Bhagat Singh seems to "possess" one of the two young men, a Ph.D. student determined to challenge enduring inequalities in Indian political life. Viewers are led to assume that he is planning an attack on the New Delhi Parliament complex, the same building Bhagat Singh bombed in April 1929 when it was the colonial government's Legislative Assembly. The specificities of this attack are not given, but we listen as the protagonist repurposes familiar fragments from Bhagat Singh's corpus: "I know 
how to tell it loud ... and make the deaf hear," he tells the friend. Or again, the assertion that, even if "the man dies, the idea stays.",59

The ambiguity over what this unnamed "citizen of India" might do in Delhi creates a tension between the specter of the bomb and Chhabra's explicit call in the film's promotional materials to update revolutionary struggle for the twenty-first century. The director hails "the digital age, where [the] megabyte is the new dynamite and [the] power of ideas and connectivity cannot be ignored." ${ }^{60}$ My interest here is in Bhagat Singh's identification as part of an exhortation toward forward movement - a prompt to keep questioning, to continue struggling - rather than as an icon of something pure to be repeated, as in the anti-corruption invocations above. This is not about freedom won and then compromised, but the idea that India remains halfway still, and thus a temporal experience of duration characterizes the political argument in the present. The question of "what does Bhagat Singh want" is answered here in terms of innovation and adaptation, rather than direct citation, an approach sensitive to the demands of the conjuncture.

Inklab was released online in 2011 via video-hosting site YouTube. An early positive response garnered an invitation to premiere the film at the International Film Festival of India (IFFI). This was stalled, however, by an intervention from the Central Board of Film Certification, which argued that the film had to be dropped due to its "anti-national" content. It suggested nine cuts on the grounds that the film was insulting to government officials. Chhabra refused, and so Inklab never made it to cinemas. ${ }^{61}$

That Chhabra's Bhagat Singh manifests as a reminder of India's imperfections may explain why Inklab provoked a hostile response, in contrast to the celebration of a film like $R D B$. Although these two films are worlds apart in style, scale, and budget, the censor's lack of concern for $R D B$ 's anti-state violence is telling: in 2007, it was submitted to the Academy Awards as India's selection for best Foreign Language Film. Inklab's warmest reception, 
meanwhile, has been amongst student groups in India, and informal campus screenings have been organized across the country. ${ }^{62}$ In this section I want to explore Bhagat Singh's apprehension in youth-dominated campus worlds as a call to keep fighting, cajoling an India that remains "halfway" to revolution. In Inklab, the protagonist's teacher is asked by police if the Ph.D. student is a threat: "Well," she answers, "to anything stagnant, anything outdated, everything that stinks of ignorance, neglect, inequality ... in this sense ... he is dangerous." A similar futurism, in league with the dead, is the object of the discussion below.

The shape and form of student politics in postcolonial India remains an understudied topic, though social scientists generally accept that students as a "demand group" typically focus on campus issues such as housing, tuition, or examinations. ${ }^{63}$ While student protestors have successfully challenged particular government regimes_famously in the $1974 \mathrm{Nav}$ Nirman Movement prompted by economic crisis and leading to the resignation of Gujarat's Chief Minister - they have "rarely challenged the centrist consensus" in Indian politics. ${ }^{64}$ This restraint is compounded by the fact that most of the major student organizations in the country operate as arms of national political parties. The National Student Union of India is associated with the Congress, the Students' Federation of India (SFI) with CPI-M, the Akhil Bharatiya Vidyarthi Parishad (ABVP) with the BJP (though, officially, it is a wing of the older Hindu nationalist organization the Rashtriya Swayamsevak Sangh), and so on. The same goes for smaller and regional parties as well as the numerous dissident offspring of the Communist Party of India.

Student politics is a necessarily transient realm; it has a "short generational cycle." ${ }^{65}$ No one can stay young or remain a student forever. For leftist student groups, this transience prompts a spatially and temporally dissident process of contextualization in the constitution of the "student activist," one that relies on tropes of solidarity through duration to structure its footing in the present. Rather than continuity through defense of territory or religious 
particularity, as perhaps binds the Hindu nationalist ABVP, or via a heritage of anticolonial overcoming, as in the Congress-affiliated National Student Union of India, an otherwise transient left student community is forged through its commitment to a revolution yet to come, through the shared experience of being halfway still. Bhagat Singh is accepted as part of the inheritance of leftist student politics in India not simply for his HSRA activism but also for his role in founding the Naujawan Bharat Sabha (Young India Association) while a student in Lahore in the 1920s. The Naujawan Bharat Sabha, established independently of mainstream Congress anticolonialism, symbolizes a youth-articulated militant spirit dating from the very beginnings of organized student politics in India.

The All-India Students' Association (AISA), which operates nationally as the student wing of the Maoist-orientated Communist Party of India (Marxist-Leninist) "Liberation" group, demonstrates the spatially and temporally dissident process of contextualization mentioned above. Although AISA was only founded in 1990 as a platform for revolutionary left students, it has mobilized as a community around a longer history of resistance, positioning itself as legatee to prior struggles. The organization expresses fidelity to the anticolonial struggle of Bhagat Singh, the 1967 Maoist uprising in Naxalbari in West Bengal, and the 1974 student movement in Bihar, among others. It connects these moments to its own history of activism, including the 1990s campaign to secure reservations for discriminated caste groups in education and the ongoing fight against Hindu nationalist chauvinism on campuses and beyond. ${ }^{66}$ The weight of this inheritance - the shared predicament of being halfway still — is apparent in AISA's frequent appeal to Bhagat Singh alongside two other martyrs: the Punjabi Naxalite poet Avtar Singh Paash, murdered on 23 March 1988, and AISA's own Chandrasekhar "Chandu" Prasad, a student leader shot by vigilantes while protesting in Bihar on 31 March 1997. These three men are celebrated together on campuses during what AISA calls "Martyrs Week," in late March: "Today when we remember these 
martyrs, we need to ask ... do we have it in our self to raise a loud voice? As the inheritors of the ideas and spirit of these martyrs, AISA pledges to raise a loud voice that shatters the current system of injustice and intensify our struggle for an India of Bhagat Singh's dreams., 67

The living are pushed forward by the dead, who simultaneously inspire and illuminate a "something-to-be-done" in the present. Continuity is conjured in terms of "movements and martyrs," as one AISA leader put it to me, ${ }^{68}$ and the student activist is constituted as one amidst a spectral gathering, a transient member of an always-shifting community. Bhagat Singh is affirmed in an AISA tract as crucial to ongoing "anti-imperialist and pro-people" struggles in India, from Naxalbari to Nandigram: "For those of us who wish to raise the voice of protest ... Bhagat Singh provides us energy and inspiration."

This dynamic of duration is evoked by the poet Paash in his essay Bhagat Singh ka Arth (The meaning of Bhagat Singh). ${ }^{70}$ Paash refers to the famous story of Bhagat Singh's last hours in Lahore Central Jail in March of 1931, when the revolutionary is interrupted by prison guards while reading a book on Lenin. He folds his page, sets the book down, and proceeds to the gallows. Paash contends that now, "Panjab ki jawanii ne uske antim din mere hue prasth se aage parha hai" (The youth of Punjab ought to read forward from the page folded on his last day). AISA's Sucheta De, then president of the highly politicized Student Union at Jawaharlal Nehru University (JNU) in New Delhi, affirmed to me in February 2012 that there is a very "natural continuation" between Bhagat Singh and contemporary leftist movements in India: "Bhagat Singh said that independence would not only mean that the British have gone from here - definitely that is one of the most important demands - but also, independence would mean that there is a fundamental change in the social structures.... If there is no change in the rights and livelihood of the most oppressed section of the society, than that is not independence [... and] that is the most troubling [issue] we are struggling 
with in this country right now." ${ }^{, 71}$ Bhagat Singh thus appears not as some anachronistic icon, but as an exhortation to action in the present.

AISA's prominence at JNU is atypical of its influence on university campuses in India, just as JNU itself, famously radical and a hub of student activism, is atypical of Indian universities. And yet the institution has tremendous symbolic importance for national student politics. Located in Delhi near the center of government power, it boasts a truly pan-Indian student body and remains one of the most highly ranked Indian universities globally. ${ }^{72}$ Its environment is highly politicized, and elaborate murals cover all available building space, addressing issues as diverse as economic inequality, Dalit (Untouchable, lit. "oppressed") rights, and feminist organization. Bhagat Singh's gaze is omnipresent: a background presence appearing on murals, notice boards and stickers as in Chhabra's Inklab, and sharing wall space with posters of Dalit leader BR Ambedkar, the reformer Jyotirao Phule, and the Hindu icon Swami Vivekananda. One particular AISA mural, observed on the side of the JNU library in late 2011 (see image 3), compels attention here for what it says about the spectral "they" conjured in the political argument. Bhagat Singh is pictured beside Lenin and Marx, and a verse from the Chilean poet Pablo Neruda's "A mi partido" (To my party) annotates the scene:

You have given me brotherhood towards the man I do not know. You have given me the freedom that the lone man lacks...

You have taught me to see unity and yet diversity of men.

You showed me how one person's pain could die in the victory of all... 


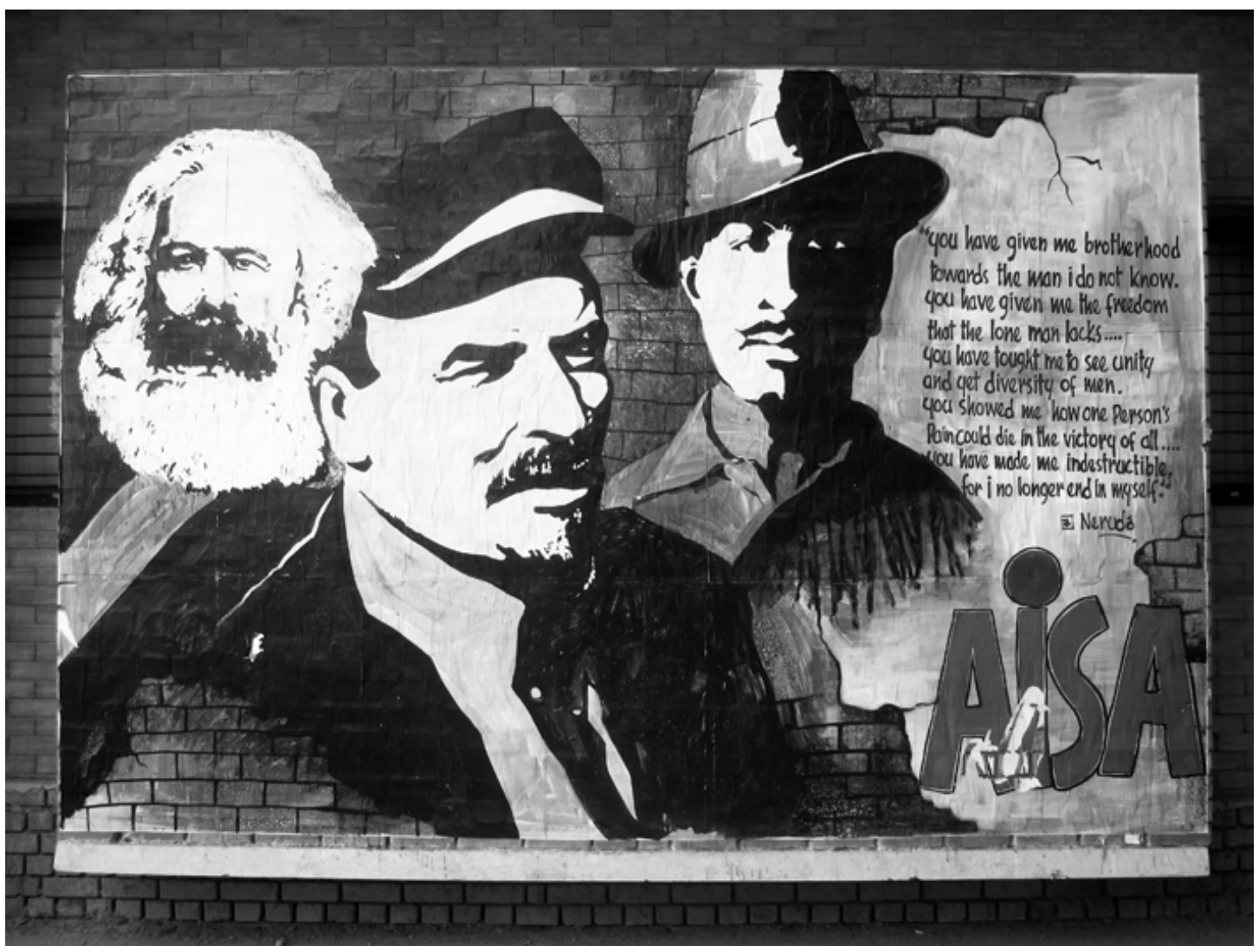

IMAGE 3: AISA MURAL, JNU, PHOTOGRAPHED BY THE AUTHOR, NOVEMBER 2011

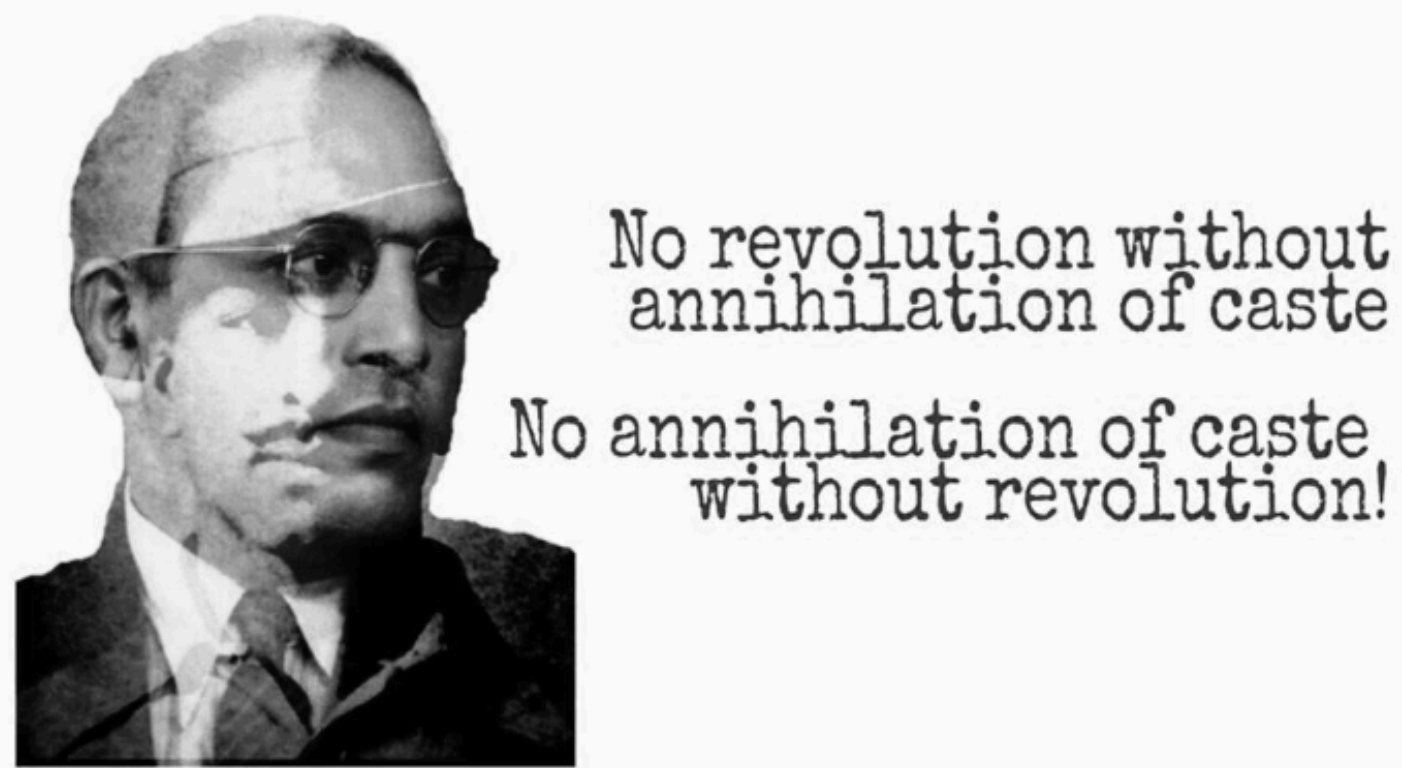

IMAge 4: BASO IMAGE OVERLAYING AMBEDKAR AND BHAGAT SingH, POSTED ON FACEBOOK, JunE 2016. COURTESY OF ANIRBAN BHATTACHARYA. 
You have made me indestructible for I no longer end in myself.

Neruda's last line is evocative here, affirming a political community that draws together the living and the dead. The juxtaposition with Marx and Lenin suggests that this solidarity defies both historical time and the spatial bounds of the nation-state: Bhagat Singh is figured amidst other modern revolutionaries, a subject at home in the world.

The importance of a global horizon for revolution recurred in my conversations with left student groups in Delhi. De, for instance, identified the then-ongoing Occupy Movement as a "space of hope." In 2015, a major protest against student funding cuts would take form as an occupation of the University Grants Commission offices in central Delhi (called \#OccupyUGC). In early 2016, the lens reversed as a global "\#StandWithJNU” movement spread from Melbourne to New York City, protesting increasing government intervention and right-wing intimidation on the distinguished campus. The action was prompted by the February arrest of several JNU students decried as "seditious" and "anti-national" following a campus event on Kashmir during which slogans in support of Pakistan were allegedly shouted. The defiance of arrested JNU Student Union president Kanhaiya Kumar, a leader in the Communist Party-affiliated All-India Students Federation, served to focus a surge of student protests already occurring in the country. The most dramatic of these had unfolded in January at Hyderabad Central University after Dalit Ph.D. student Rohith Vemula committed suicide, the tragic outcome of sustained bullying from right-wing student groups and university administrators. ${ }^{73}$

Kumar said in press interviews that Bhagat Singh had provided his "first inspiration" to enter politics, but he also insisted that the Indian left must make an alliance with Ambedkarites-Dalit activists continuing the work of early twentieth-century anti-caste thinker B. R. Ambedkar-and address more forcefully the recalcitrance of caste in contemporary political life. ${ }^{74}$ This suggestion was controversial, since Dalit activists have 
traditionally seen educated, urbanized leftist groups in India as perpetuating structures of caste. But Kumar's call was echoed by two other Ph.D. students arrested in February 2016, Anirban Bhattacharya and Umar Khalid, who upon their release founded the "Bhagat Singh Ambedkar Student Organisation" at JNU. Their motto, referencing one of Ambedkar's famous essays, was "No Revolution without Annihilation of Caste; No Annihilation of Caste without Revolution" (see image 4). ${ }^{75}$ The group's foundation, in the wake of Vemula's suicide, was met with skepticism by Dalit groups on campus, ${ }^{76}$ but Bhattacharya insisted in a June 2016 conversation that their organization was inaugurated "to send a very strong message to the left" with regard to how it integrates questions of caste, and indeed patriarchy, into its understanding of class struggle: "If we are not taking a position on these questions, not making it part of the larger agenda of revolution itself, then what revolution may we have?" When asked why this novel political alliance needed to take form under the sign of two early twentieth-century political figures, Bhattacharya affirmed without hesitation that there is direct continuity between the struggles announced by Bhagat Singh and Ambedkar and the obstacles faced today: "That war still exists."77

Some caution around the promise of Bhagat Singh was offered in an earlier interview with Roshan Kishore of the CPI-M affiliated SFI. This organization also locates its origins in the anticolonial period, even if it was officially founded in December 1970 following a rupture from Kumar's All-India Students Federation. Kishore, then state president of the Delhi SFI, ${ }^{78}$ told me in April 2012, "Far from being irrelevant or clichéd, [Bhagat Singh's ideas] still hold a lot of importance for our society." But he also insisted that the revolutionary should be seen as one among many martyrs to progressive causes. Bhagat Singh may be an iconic figure useful for propaganda purposes, he continued, but ultimately such a focus on one person is damaging for a mass movement. ${ }^{79}$ Kishore's comments express a discomfort with the individualist potential of the heroic, armed revolutionary, and 
demonstrate a pragmatic concern with the institutional requirements of organized struggle. But at the same time, his opinion is perhaps more representative of the CPI-M at large than of student politics specifically, by which I mean that there is arguably something appropriate about Bhagat Singh's excessive, youthful potentiality as it intersects with the heightened stakes of student politics. The campus, populated as it is by youth, preceding and so exempt from the obligations of age and career, is in many ways the ideal location for the pursuit of departure and individual action demanded by a revolutionary inheritance. In this space, Bhagat Singh's stake in the achievement of radical change is affirmed, for this achievement would not be simply a reward for the living but would also serve to redeem the dead. This idea of a shared struggle that may one day be resolved inspires commitment among the transient leftist student community; even if the sequential model it follows is liable to stutter, the promise of redemption remains. The next section dispenses with the promise of redemption altogether to consider how the specter of Bhagat Singh may weigh upon everyday life, in perpetuity.

\section{V. “OUR HEROES ... ARE SHADOWING YOUR TYRANTS"}

In April 2013, several state governments in north India decided to ban, on the eve of its release, a new Punjabi film called Sadda Haq (Our Right). ${ }^{80}$ At issue was the film's potential to negatively affect "communal harmony" in the region. Sadda Haq is set during the high period of police repression in Punjab, its story unfolding in the years after 1984 when an anxious central government responded to insurgent demands for an independent Sikh territory_-"Khalistan"—with widespread and often indiscriminate detentions, torture, and executions of young Sikh men. ${ }^{81}$ The film follows the fictional Kartar Singh Bazz and his decision to take up arms against the Indian government. Though it had been certified by the 
central Film Board, concerns over graphic scenes of torture and the alleged glorification of separatist violence prompted the state-level ban. Government caution was praised by Ajay Seth, president of the Amritsar District Shiv Sena, who claimed Sadda Haq was "an attempt to bring back militancy to Punjab." ${ }^{, 82}$ His satisfaction was short-lived, however. An appeal to the Supreme Court by the film's producer Kuljinder Singh Sidhu succeeded in having the ban overturned by May 2013.

The flash of anxiety sparked by Sadda Haq is revealing. For Seth and the Hindu nationalist Shiv Sena, and not least for Punjab's state government, the film conjured a past that was supposed to have passed, a sequence that began in the 1970s and which had been (impatiently) closed in the mid-1990s. The year 1984 looms large in this repressed imaginary, encompassing the Indian army's “Operation Bluestar" offensive against Sikh militants in Amritsar's Golden Temple complex that June, the assassination of Prime Minister Indira Gandhi by her Sikh bodyguards four months later, and, the next day, the organized massacre of innocent Sikhs across North India in retaliation. The idea of "1984" once worked to incite, drawing Sikh youth to defend their honor and giving Khalistan a credibility it had not possessed before Bluestar. Now, it works to signal the "bad old days," a period of vigilante killings, police abductions and communal violence now left behind. The conflict was largely exhausted by the mid-1990s, contained by the now-notorious Punjab police chief KPS Gill, but the thirtieth anniversary in 2014 saw renewed discussions around responsibility for the Delhi pogroms and commentaries on the resurgent popularity of the Sikh leader killed in Operation Bluestar, Jarnail Singh Bhindranwale. ${ }^{83}$ Sadda Haq risked resuscitating unfinished business.

It is curious, then, that the controversy over Sadda Haq first emerged around a promotional music video that had at its heart a distinctly trans-historical identification: that is, the Punjabi folk figure of the baghi (rebel, insurgent), who is compelled to challenge a 


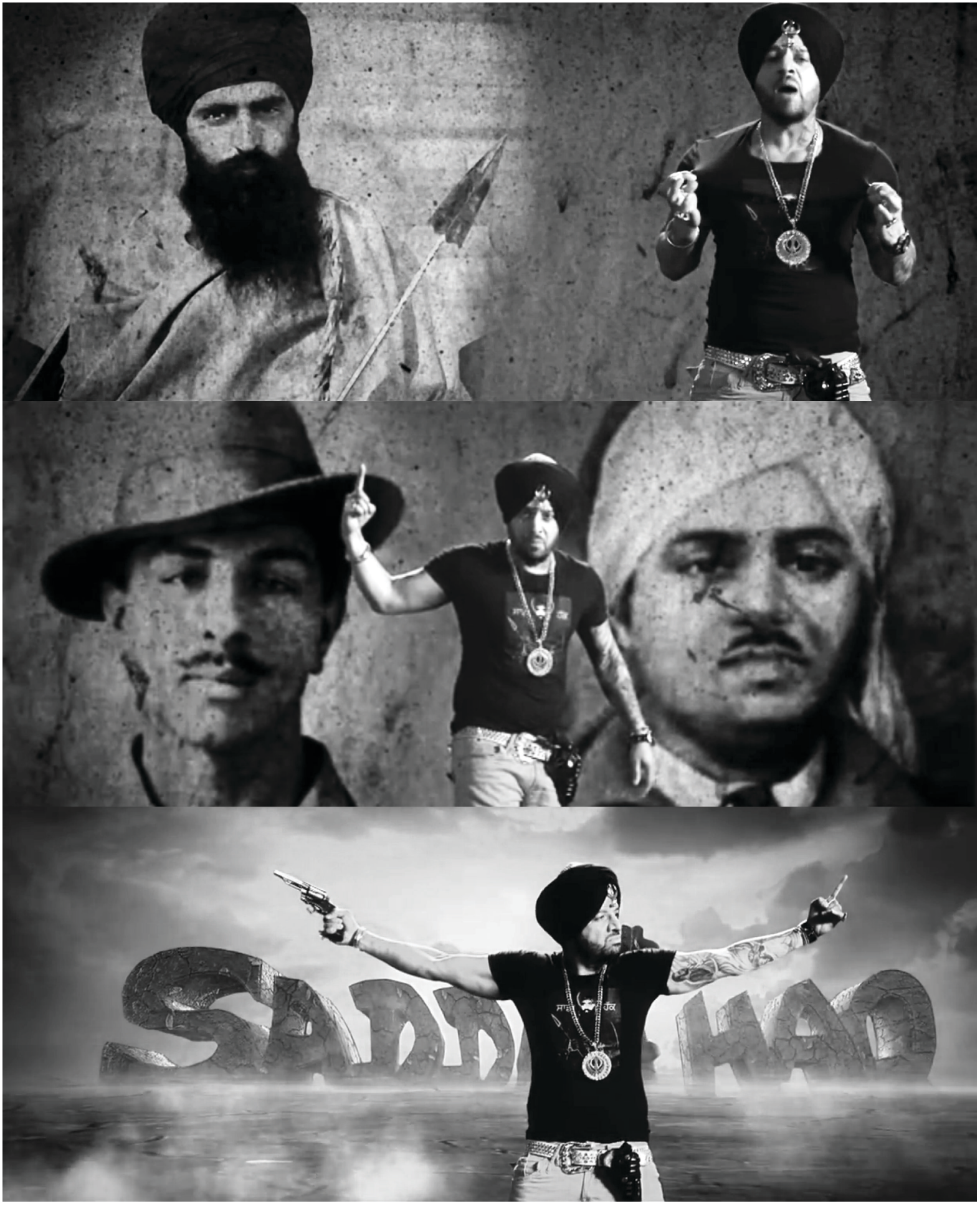

IMAGE 5: STILl FROM JAZZY B, 'BAGHI’ (2013). COURTESY OF JAZZY B MANAGEMENT. 
condition of zulm (tyranny, oppression) whenever it may appear. In the video for "Baghi" (see image 5), the popular bhangra singer Jaswinder Singh Bains (“Jazzy B”) appears interspersed with clips from Sadda Haq, wielding guns and flexing his muscles against a backdrop of images from six centuries of Sikh history. The lyrics recite a long list of warrior heroes associated with the religious tradition: from Mughal-era figures like Guru Gobind Singh and Hari Singh Nalwa to anticolonial icons like Bhagat Singh and Udham Singh, and finally, to recent figures like Bhindranwale and Khalistani militants Balwant Singh Rajoana and Jagtar Singh Hawara. These historically-diverse figures are incorporated under one name, baghi, which itself refers to the Punjabi proverb that contends a Sikh can only be a king or a baghi; that is, if the Sikh male, specifically, ${ }^{84}$ cannot rule, then he is bound to fight those who do rule. There is no middle path between these ways of controlling one's own destiny, and each is perpetually under threat from its other. ${ }^{85}$

Jazzy B's unapologetic invocation of Bhindranwale — not to mention Rajoana and Hawara, both of whom remain in prison in connection with the 1995 assassination of Punjab Chief Minister Beant Singh—is not remarkable in itself: Bhindranwale's revenant presence in twenty-first-century Punjab is readily apparent, and the song echoes the ubiquity of his image on bumper stickers and T-shirts. ${ }^{86}$ It was not simply invocation, then, but the gesture of incorporation that prompted criticism: the song's suggestion that hallowed "freedom fighters" like Bhagat Singh could be spoken of as "in the same vein" as Sikh militants, an alignment Congress MP Ravneet Singh Bittu suggested "tries to glorify terrorism." ${ }^{\text {"It }}$ is perhaps significant that the Punjab-born Jazzy B has spent most of his life in Vancouver; Sadda Haq, like the idea of Khalistan itself, has found an enthusiastic audience among the Canadian Sikh diaspora. ${ }^{88}$

And yet Bhagat Singh's enduring popularity in Punjab, and among Sikhs in general, is enabled precisely because his life and death align so well with established narratives of 
heroism and honorable action in the community. The baghi figuration strips Bhagat Singh of historical particularity, but in doing so ensures his identification as a worthy interlocutor and model of action against abuses of power. ${ }^{89}$ My concern here is thus not to critique Jazzy B's "appropriation" of Bhagat Singh into a distinctly Sikh pantheon, but rather to note how this alignment allows the revolutionary to defy relegation to the past and, in spectralized form, authorize certain ideas of action and responsibility in the postcolonial present. ${ }^{90}$

The baghi is a figure prompted by a relational dynamic and so defined in terms of action and stance rather than any precise idea at stake in a struggle. This responsive, recalcitrant subjectivity, tempted forward by the tyranny of the powerful, is often portrayed as a "natural" product of the Punjab itself-idealized due to the harsh realities of life at India's frontier and the experience of constant invasions, from Alexander the Great to the British ${ }^{91}$ — but also of the Sikhs in particular, a community animated by histories of persecution and marginalization from the subcontinent's power struggles. During the years of the Punjab insurgency, a turbaned Bhagat Singh, born of Punjabi soil, was accepted as iconic of the noble Sikh tradition of taking up arms against repression. ${ }^{92}$ He was tied equally to a proud tradition of dying for a just and righteous cause, a tradition of shahadat (martyrdom) complementing necessarily the baghi's compulsion to enter battle. ${ }^{93}$ As Ishwar Dayal Gaur demonstrates, Bhagat Singh's death politics have been constantly filtered through religious tropes of a hero "who fights for the sake of the wretched." "94

As Louis Fenech has argued, the role of shahadat in constituting the Sikh community was consolidated by religious organizations like the Singh Sabha in the late nineteenth century, partially in response to the proselytizing efforts of Christian missionaries and Hindu reformists in Punjab. "Martyrologies"- stories of struggle and sacrifice—were circulated and popularized with an aim to "inspire Sikhs ... to bear their daily tribulations and resist the tyranny of oppression." 95 Figures from the past were invited to populate the present as visions 
of honor upheld. As Gaur notes, the figure of the martyr in Punjabi literature is characterized by its refusal to abide by sequential time, emerging as "one who survives as an independent force in history and appears/reappears boldly of his/her own accord to defy the exploiters and the wicked."96

In analyses of Bluestar's protracted and bloody nature, the government's poor preparation is often attributed to their desire to conceive as mere criminals men who saw confrontation with the state as a duty and death as a gift. ${ }^{97}$ Martyrdom, indeed, would allow entry into a culturally revered category and alignment with an honored assembly of the dead. Two years after Bluestar, the chief of Army Staff responsible for the Golden Temple offensive, General AS Vaidya, was assassinated by two Khalistani militants in Pune: Harjinder Singh "Jinda" and Sukhdev Singh "Sukha." Sentenced to death for the act, Sukha and Jinda addressed an open letter to the president of India to situate their act within a righteous tradition. Released in July 1990 by the Panthic Committee, ${ }^{98}$ the letter positioned Vaidya's killing as "part of the same battlefield strategy that was once used by our heromartyrs Madan Lal Dhingra, Bhagat Singh, Kartar Singh Sarabha, and even today it is used by revolutionaries the world over, and considered right." 99 Violent action is demanded by the condition of zulm, and though the three figures invoked here are Punjabi-Dhingra, from Amritsar, assassinated a colonial official in London in 1909, while Sarabha, a founding member of the Ghadar ("Rebellion") Party, was hanged in Lahore in 1915—Sukha and Jinda elsewhere cite Che Guevara and Nelson Mandela, not for their historical particulars but for their decision to choose suffering rather than a dishonorable peace. The baghi cannot but resist, they continue: "By performing our historic task we have reminded you that our heroes like Sukha Singh, Mehtab Singh, [and] Udham Singh are shadowing your tyrants like Wazida, Lakhpat, Rebeiro, [and] Dawyer [sic]."100

Bhagat Singh is only one amidst a crowded congregation here, but all are contemporaries 
in this ongoing confrontation with zulm. The baghi is, in a sense, the proper, perpetually vigilant subject demanded by Bhagat Singh in his 1929 definition of revolution: "Old order should change, always and ever, yielding place to new, so that one 'good' order may not corrupt the world." 101 Every manifestation of power will produce its baghi, so that even the independent Sikh state Sukha and Jinda demand will not be free from a dissident other. Until that state is formed, however, it remains a banner to wave against contemporary injustice. ${ }^{102}$ Jazzy B's invocation of the baghi is, admittedly, less solemn. His proud conjuring of Bhagat Singh strikes a stark contrast to the usual ornaments of his music videos as selfappointed "Crown Prince" of the pop genre bhangra: expensive cars, alcohol, and dancing women. ${ }^{103}$ Aside from this surface dissonance, the predicament of a perpetual "halfway" point enshrined in the baghi aligns compellingly with tropes of Jat Sikh masculinity in the music and films of figures like Jazzy B. "Jat" names the demographically and economically dominant caste group of Sikhs in Punjab, primarily associated with agrarian pursuits. The group's regional authority, secured via widespread land ownership, fuels a sense of guardianship over traditional Punjabi culture and morality, though this assumption of supremacy exists in tension with an oft-lamented narrative of economic and political marginalization vis-à-vis the central Indian government: Jat Sikhs appear "hegemonic while resistant," in Nicola Mooney's phrase. ${ }^{104}$ The popular genre of bhangra is frequently noted for its "Jatcentric" themes, and indeed one of Jazzy B's earlier hits was called, plainly, "Jatt." ${ }^{105}$ Bhagat Singh, born into a Jat Sikh family, is resonant here not simply for his advocacy of righteous struggle but also because he embodies the masculine values of the dominant community: virility, honor, and self-sufficiency. The revolutionary's charismatic recalcitrance stands as a more principled precedent for bhangra "swagger"; so too is the frequent depiction of the revolutionary with a pistol a mirror for contemporary outlaw posturing. And it is not only Jazzy B who interrupted his usual concern with masculine 


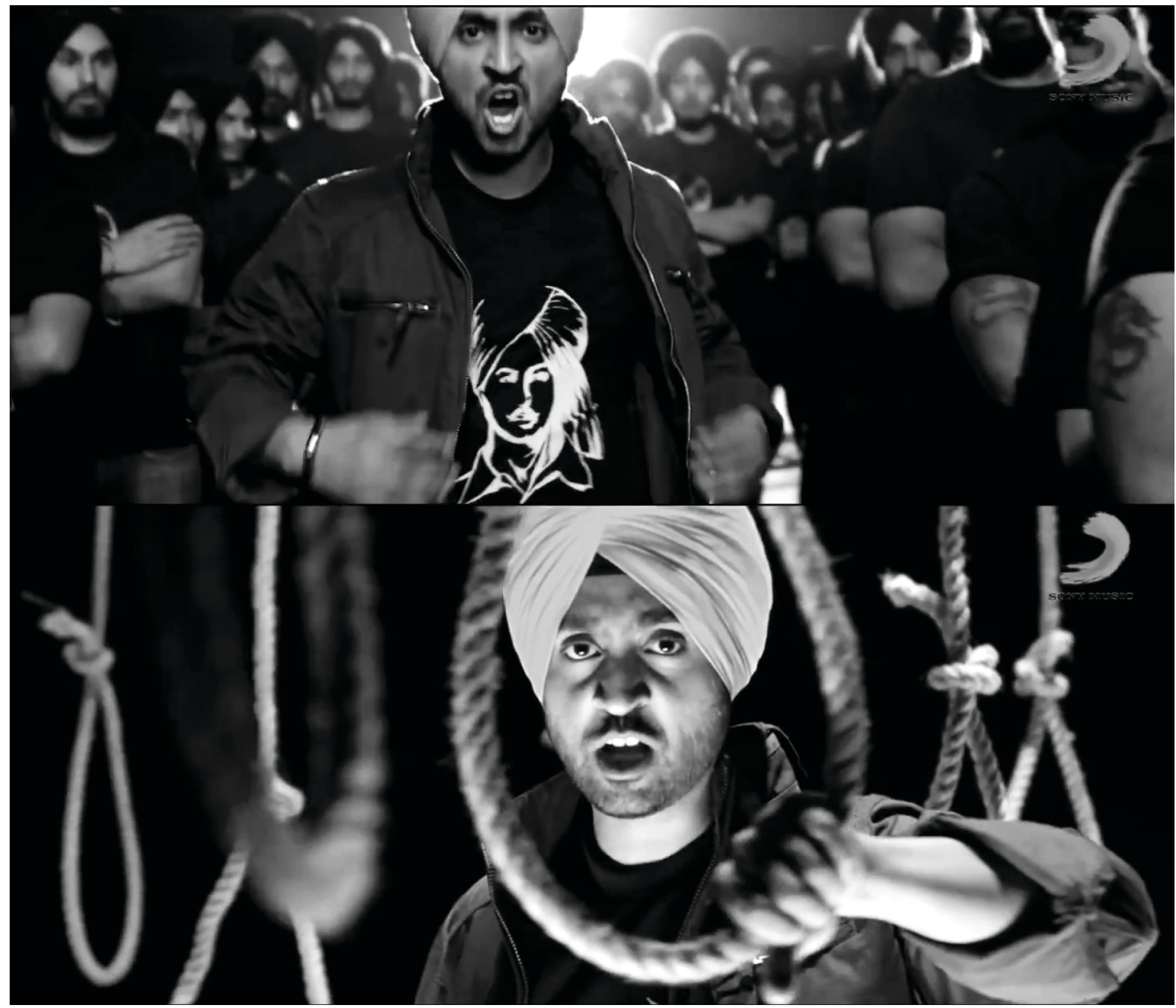

Image 6: Stills From Diljit Dosanjh, “Main FAn Bhagat Singh DA” (2013).

enjoyment with this serious nod to the baghi; major figures in the genre like Diljit Dosanjh and controversial superstar Yo Yo Honey Singh have released songs specifically honoring Bhagat Singh (see image 6). ${ }^{106}$ The point is not that these are departures, however. Rather, the "something-to-be-done" represented by Bhagat Singh is aligned here, in spectralized form, to authorize an everyday ethic of masculine performance and individual entitlement.

These tropes of muscular swagger are not bound solely to Jat Sikh youth cultures. We have already seen the BSKS's deployment of a strident revolutionary figure wielding a wooden plank. But how can celebrated popular singers and majoritarian organizations like the BSKS be said to experience their present as $z u l m ?^{107}$ The Sena, certainly, speak with the 
voice of a dominant majority, focusing violence on internal enemies rather than tyrannical oppressors. The "unfinished business" animating their politics is contrasted starkly with Bhagat Singh's resonance during the Punjab insurgency, a time characterized by targeted killings, mass detentions, and a pervasive atmosphere of terror. This demonstrates how a baghi subjectivity, so intimately bound to shifting manifestations of zulm in Punjab's cultural imaginary, can be translated into a more general individualist stance and, certainly in the case of bhangra, transformed into an item to be consumed, a persona to capitalize on commercially.

But this idea of the co-constituting relationship between the tyrant and its other remains compelling in other parts of the Indian state, especially the contested territory of Jammu and Kashmir, where a large military presence persists after decades of insurgency and secessionist struggle. On 9 February 2013, a man charged with playing a role in this insurgency was hanged in Tihar Jail, New Delhi. The Kashmir-born Afzal Guru had been accused of aiding the Islamic militant groups Lashkar-e-Taiba and Jaish-e-Mohamed in their 13 December 2001 attack on the Indian Parliament, and was controversially condemned with questionable evidence. ${ }^{108}$ On the day he was hanged, Afzal's supporters circulated on social networking sites an image of the Lahore Tribune from 25 March 1931. This edition reported Bhagat Singh's execution, proclaiming, "No last interview with relatives" and "Dead bodies secretly disposed of." These headlines resonated with controversies over Afzal's secretive hanging, and a similar dismissal of his family's campaign for a reprieve. Both men were hanged under the same charge: Section 121 of the Indian Penal Code, conspiring to wage war against the government, though Bhagat Singh's affirmation of his act provides a contrast to Afzal's apparent innocence. An op-ed on the online news site DNA India asked, "What forced the rulers of a democracy today to follow the footsteps of their colonial masters?" "It's not merely the trial alone but the macabre manner in which he was sent to gallows that has 
elevated Afzal's status to that of Bhagat Singh before the eyes of almost every Kashmiri, irrespective of his/her political affiliations." ${ }^{, 109}$ Small demonstrations took place in Delhi after the event, during which protestors demanded the return of Afzal's body. Placards read, "Return Afzal Guru's body," and "If Bhagat Singh is your martyr, then Afzal Guru is ours."110

The reception of Afzal Guru's death in Kashmir - not as a criminal or a terrorist but as the victim of a repressive state - signals the unfinished business that continues to shape politics in that region: the temporal experience of being "halfway" to freedom, expressed in a simmering call for self-determination. The analogy to Bhagat Singh allows me to reiterate how the state itself can conjure enemies into being, and the ambivalent legacy the anticolonial struggle leaves in this regard. Some months after the execution of Afzal Guru, Syed Ali Shah Geelani, founder of the Hurriyat Conference for self-determination in Kashmir, attracted criticism for defending stone-pelting as a legitimate means for the helpless in Kashmir to express resentment against police. He pointed, in this conversation, to the popularity of Bhagat Singh in India: the gun, he said, "was also a factor which incremented and supplemented India's freedom movement. So, any nation which is under forcible occupation, suppression and oppression, you cannot put limits on them." ${ }^{111}$ India here, as for the Khalistanis above, provides the prompt for a militant response, in its complicity in perpetuating zulm, against which the shaheed manifests as a possibility. Guru is not characterized in baghi terms, but his treatment by the Indian government is seen as authorization for a determined opposition. He will continue to hold a stake in the political argument of modern Kashmir, joining an assembly of the dead holding the present to account.

\section{CONCLUSION}


This article has demonstrated how and why historians should attend to the question of afterlives, drawing on the case of India to illustrate how the demands of inheritance can inform politics and political thought in a given present. I have focused on the variant ways living communities negotiate a sense of responsibility to the martyred revolutionary Bhagat Singh, greeting him as an interlocutor in a common predicament rather than an anachronism from a sequence now passed. This vision of a political community that draws together the living and the dead is intended to invite further conversation on the force and effects of anticolonial pasts in postcolonial presents, in India and more generally.

One point to emphasize in conclusion is that the dead are treated here not as burden or traumatic remnant but as figures of clarification, illuminating the "something-to-be-done" in the present. This is the terrain on which it is possible to ask, "What does Bhagat Singh want?" The martyr is seen to hold individuals responsible for their successes and failures, and their contributions to a struggle in which he continues to hold a stake. Action, in this case, provides the primary form of responsibility to the dead. Through a comparison of three different political projects, I have demonstrated how a revolutionary inheritance, taken seriously, troubles the consolidation of new, national institutions and alternative, postcolonial legalities, propelling a dissensual politics. The dead man's exhortation to departure is not, however, paired with a certainty of destination, and indeed the ambiguity surrounding what a struggle completed might look like facilitates Bhagat Singh's enduring, promiscuous appeal in twenty-first-century India. Rather than searching for a precise program, a criteria by which to judge "correct" or "incorrect" receptions, this article has followed the convulsions of a promise, one heavily conditioned by fantasies of partisanship and the black-or-white fidelities of anticolonial struggle, the desire for a clarity that is perhaps no longer attainable but which continues to incite allegiance. 
The question of "afterlives" cannot be fully addressed by conventional histories of reception, which adopt the "decisionist" approach to the past explained in the article's introduction. In accepting the possibility of a "haunting," my aim is not to attribute a ghostly agency to the dead but rather to inject doubt into this insistence on the autonomy of the living - the presumption that we stand, confidently, in an emancipated present, able to draw selectively from the past but remaining in no way bound to it. To acknowledge the work of the dead is to accept that the living may face the future but can be distracted, deterred, or roused by their sense of obligation, duty, or debt to the heroes or victims of struggles past. The concept of inheritance offers a language for grappling with this untimely interference, for understanding how this spectral weight is experienced as a call to responsibility, an incitement to action, and through which the outcomes of new political struggles have consequences not just for the living but for the honor and dignity of the dead themselves. 
Abstract: This article provides a framework for understanding the continuing political potential of the anticolonial dead in twenty-first-century India. It demonstrates how scholars might move beyond histories of reception to interrogate the force of inheritance in contemporary political life. Rather than the willful conjuring of the dead by the living, for a politics in the present, it considers the more provocative possibility that the dead might themselves conjure politics — calling the living to account, inciting them to action. To explicate the prospects for such an approach, the article traces the contested afterlives of martyred Indian revolutionary Bhagat Singh (1907-1931), comparing three divergent political projects in which this iconic anticolonial hero is greeted as interlocutor in a struggle caught "halfway." It is this temporal experience of "unfinished business"—of a revolution left incomplete, a freedom not yet perfected — that conditions Bhagat Singh's appearance as a contemporary in the political disputes of the present, whether they are on the Hindu nationalist right, the Maoist student left, or amidst the smoldering remains of Khalistani separatism in twenty-first-century Punjab. Exploring these three variant instances in which living communities affirm Bhagat Singh's stake in the struggles of the present, the article provides insight into the long-term legacies of revolutionary violence in India and the relationship between politics and the public life of history in the postcolonial world more generally.

Key words: martyrdom, inheritance, revolution, haunting, afterlives, politics, Bhagat Singh, India 
Acknowledgments: I owe thanks to Shruti Kapila, C. A. Bayly, Christopher Pinney, Faisal Devji, Kama Maclean, Karuna Mantena, Virinder S. Kalra, Faridah Zaman, and Rachel O’Neill for comments on earlier versions of this essay. The piece benefited from discussions at the 2015 Yale Modern South Asia Workshop and the perceptive commentary provided by the $\mathrm{CSSH}$ editors, anonymous reviewers, and Managing Editor David Akin.

${ }^{1}$ Avery Gordon, "Some Thoughts on Futurity and Haunting," borderlands 10, 2 (2011): 1-21, 2; and Ghostly Matters: Haunting and the Sociological Imagination (Minneapolis, 1997), 7; Peter Fritzsche, "Specters of History: On Nostalgia, Exile, and Modernity," American Historical Review 106, 5 (2001): 1587-1618.

${ }^{2}$ Gordon, "Some Thoughts," 2.

${ }^{3}$ Dipesh Chakrabarty, Provincializing Europe: Postcolonial Thought and Historical Difference (Princeton, 2008), 247.

${ }^{4}$ Dominick LaCapra, “Trauma, Absence, Loss,” Critical Inquiry 25, 4 (1999): 696-727; Cathy Caruth, Unclaimed Experience: Trauma, Narrative, and History (Baltimore, 1996).

${ }^{5}$ Elizabeth Freeman, Time Binds: Queer Temporalities, Queer Histories (Durham, 2010).

${ }^{6}$ Jacques Derrida, Specters of Marx, Peggy Kamuf, trans. (London, 2006 [1994]); Michael Sprinkler, ed., Ghostly Demarcations: A Symposium on Jacques Derrida's Specters of Marx (London, 1999); Nissim Mannathukkaren, The Rupture with Memory: Derrida and the Spectres that Haunt Marxism (Pondicherry, 2006).

${ }^{7}$ Chakrabarty, Provincializing Europe, 15.

${ }^{8}$ Gordon, Ghostly Matters, 139.

${ }^{9}$ David Scott, Refashioning Futures: Criticism after Postcoloniality (Princeton, 1999).

${ }^{10}$ See Interventions 10, 1 (2008) issue entitled "Under which Flag? Revisiting James Connolly"; and Shannen L. Hill, Biko's Ghost: The Iconography of Black Consciousness (Minneapolis, 2015).

${ }^{11}$ Sumathi Ramaswamy, The Goddess and the Nation (Durham, 2010); Louis E. Fenech, Martyrdom in the Sikh Tradition (New Delhi, 2000).

${ }^{12}$ On Bhagat Singh's life and context, see Kama Maclean's important A Revolutionary History of Interwar India (London, 2015).

${ }^{13}$ Chris Moffat, “Bhagat Singh's Corpse,” South Asia: Journal of South Asian Studies 39, 3 (2016): 644-61.

${ }^{14}$ Jacques Rancière, Disagreement: Politics and Philosophy, Julie Rose, trans. (Minneapolis, 1999), esp. ch. 
3.

${ }^{15}$ Émile Benveniste, Problems in General Linguistics, Mary Elizabeth Meek, trans. (Miami, 1971), 197-98. I am indebted to a $\mathrm{CSSH}$ reviewer for this reference.

${ }^{16}$ Mridula Garg, Anitya: Halfway to Nowhere, Seema Seghal and Krishna Dutt Paliwal, trans. (Delhi, 2010), 68,95 .

${ }^{17}$ Ibid., xii, “Author's Note.”

${ }^{18}$ Ibid., 195.

${ }^{19}$ Chris Moffat, "Experiments in Political Truth,” Postcolonial Studies 16, 2 (2013): 185-201.

${ }^{20}$ Garg, Anitya, xii, “Author's Note.”

${ }^{21}$ On "context" versus "contextualization," see Richard Bauman and Charles Briggs, "Poetics and Performance as Critical Perspectives on Language and Social Life," Annual Review of Anthropology 19 (1990): $59-88$.

${ }^{22}$ Rang de Basanti, directed by Rakeysh Omprakash Mehra (URV Motion Pictures, 2006).

${ }^{23}$ On the film's early reception, see Namrata Joshi, "My Yellow Icon,” Outlook, 20 Feb. 2006.

${ }^{24}$ Neelam Srivastava, "Bollywood as National(ist) Cinema: Violence, Patriotism and the National-Popular in Rang De Basanti,” Third Text 23, 6 (2009): 703-16, 713.

${ }^{25}$ For an early account, see Mitu Sengupta, "Anna Hazare and the Idea of Gandhi,” Journal of Asian Studies 71, 3 (2012): 593-601.

${ }^{26}$ Anna Hazare, speaking in Ralegan Siddhi prior to Hazare’s December 2011 fast in Delhi. See "People Will Castigate Govt if Lokpal Bill Is not Brought before House: Anna," Daily News \& Analysis (DNA) India, 10 Dec. 2011.

${ }^{27}$ Kala dhan is money stored in foreign banks for purposes of tax evasion.

28 “Anna Hazare Hungry for Another Fast,” DNA India, 9 June 2011. Also see Saroj Giri, “The Anti-

Corruption Movement and Its False Divides,” Economic \& Political Weekly 46, $26 / 27$ (25 June 2011): 14-16.

29 "People Will Castigate Govt."

${ }^{30}$ Anna Hazare (@ShriAnnaHazare) Twitter account, message posted 24 Mar. 2013, 9:38 IST.

31 "People Will Castigate Govt."

32 “Anna Hazare Blames Politicians,” TIMESNOW.tv, 7 Apr. 2011, http://www.timesnow.tv/articleshow/msid-4369758,prtpage-1.cms (last accessed Mar. 2016).

33 “Hazare Turns Down Z-Category Security,” Hindustan Times, 4 Sept. 2011. 
34 “PC Told Lies on Many Occasions: Anna,” Outlook, 2 Sept. 2011, http://outlookindia.com/news/article/PC-Told-Lies-on-Many-Occasions-Anna/733376 (last accessed Apr. 2016).

${ }^{35}$ Shiv Visvanathan, “Op-Ed: Fading Memory of Nationalism,” Deccan Chronicle, 22 Apr. 2011.

36 “For Fasters, There Was Only Hunger to Succeed," Times of India, 28 Aug. 2011.

37 “Baba Ramdev Rejects Centre’s Appeal,” India Today, 3 June 2011, http://indiatoday.intoday.in/story/baba-ramdev-rejects-appeal-of-centre-to-begin-satyagraha/1/140306.html (last accessed Mar. 2016).

38 “For Team Anna, Left Is Right," Hindustan Times, 22 Aug. 2011.

${ }^{39}$ The BSKS publicize their various campaigns and protests via social media. See their current Facebook account https://www.facebook.com/ShahhedBhagatSingh/ and Twitter account www.twitter.com/BSKS_India (last accessed Feb. 2017). Their blog www.bhagatsinghkrantisena.blogspot.co.uk has fallen out of use since 2013 but contains early press statements.

${ }^{40}$ Thomas Blom Hansen, The Saffron Wave (Princeton, 1999), 93.

${ }^{41}$ The BSKS manifesto appeared on the organization's original (now-defunct) Facebook page, www.facebook.com/bhagatsinghkrantisena (accessed 16 Oct. 2011, screenshot with author).

42 “Three Attack Prashant Bhushan for Kashmir Remarks,” IBN Live, 12 Oct. 2011, http://ibnlive.in.com/news/three-attack-prashant-bhushan-for-kashmir-remarks/192453-3.html (last accessed Mar. 2016).

${ }^{43}$ On Indian nationalism's deep investment in Kashmir, see Ananya Jahanara Kabir, Territory of Desire (Minneapolis, 2009).

44 "Prashant Bhushan Tried to Break India, I Broke His Head," Times of India, 13 Oct. 2011. Only one member, Inder Verma, seen in the Times Now video beating Bhushan, was arrested.

${ }^{45}$ On the HSRA's relationship to anarchism, see J Daniel Elam, “The 'Arch-Priestess of Anarchy' Visits Lahore," Postcolonial Studies 16, 2 (2013): 140-53.

${ }^{46}$ Interview with Tajinder Pal Singh Bagga and Vishnu Gupta, New Delhi, 14 Dec. 2011. Also see the Hindi edition of Tehelka, 31 Oct. 2011, for a profile of Bagga.

${ }^{47}$ Simona Sawhney, "Death in Three Scenes of Recitation," Postcolonial Studies 16, 2 (2013): 202-15. This marks a significant departure from martyrdom's centrality to the formation of the patriotic male in late colonial India, as observed in Ramaswamy, Goddess. 
${ }^{48}$ These actions are traced out on the group's Facebook page, but also see: "Serial Offender Bagga Danced on Mirwaiz’s Car," Sunday Guardian, 16 Oct. 2011; “Protesting Group Tries to Burn Constitution at J\&K House,” Pioneer, 26 Jan. 2012; “Kak’s Film Screened amid Tight Security in Delhi,” Hindu, 17 Feb. 2012; "Right-Wing Activists Badger Geelani at Event in City,” Hindustan Times, 26 Mar. 2012; and "CD Row: Congress MP Abhishek Manu Singhvi Quits Official Posts,” IBNLive, 23 Apr. 2012, http://ibnlive.in.com/news/cd-row-congress-mp-abhishek-manu-singhvi-quits-official-posts/251385-44.html (last accessed Mar. 2016).

${ }^{49}$ Christiane Brosius, Empowering Visions: The Politics of Representation in Hindu Nationalism (London, 2005), 273

${ }^{50}$ Ibid., 81, 303 n61.

${ }^{51}$ Sitaram Yechury, “Op-Ed: An Exercise in Sheer Duplicity,” Hindustan Times, 24 Mar. 2014.

${ }^{52}$ Harald Fischer-Tiné, Shyamji Krishnavarma: Sanskrit, Sociology and Anti-Imperialism (Delhi, 2014).

Also consider Modi’s advances toward Vallabhbhai Patel: Shruti Kapila, "Why Narendra Modi Is Claiming Sardar Patel's Legacy,” Economic Times, 3 Nov. 2013.

${ }^{53}$ Saroj Giri, "Pehele AAP, pehele AAP, phir Modi,” Sanhati, 10 Dec. 2013, http://sanhati.com/excerpted/8713/ (last accessed Mar. 2016).

${ }^{54}$ Faisal Devji, The Impossible Indian (London, 2012).

${ }^{55}$ William Mazzarella, "Branding the Mahatma: The Untimely Provocation of Gandhian Publicity," Cultural Anthropology 25, 1 (2010): 1-39.

${ }^{56}$ Christopher Pinney, "The Body and the Bomb: Technologies of Modernity in Colonial India," in Richard Davis, ed., Picturing the Nation: Iconographies of Modern India (New Delhi, 2007), 51-65, 64.

${ }^{57}$ Inklab, directed by Gaurav Chhabra (Independent Release, 2011).

${ }^{58}$ See the Facebook page www.facebook.com/inklabmovie (last accessed Mar. 2016). The film is available online: see "Inklab," posted by user "humlog" on YouTube, 7 Apr. 2012, https://www.youtube.com/watch?v=59Ajx0vVPZA (last accessed Mar. 2016).

${ }^{59}$ The dialogue cited maintains the English subtitles provided by Chhabra.

${ }^{60}$ See "About" section at www.facebook.com/inklabmovie (last accessed Mar. 2016)

61 "Film on Bhagat Singh Dropped from IFFI," Hindu, 26 Nov. 2011.

${ }^{62}$ Interview with Gaurav Chhabra, Chandigarh, 27 Mar. 2012.

${ }^{63}$ See Lloyd I Rudolph and Susanne Hoeber Rudolph's classic In Pursuit of Lakshmi: The Political 
Economy of the Indian State (Chicago, 1987), ch. 11; also, Rashid Syed Ali, Cultures of Student Politics (Delhi, 1997).

${ }^{64}$ Rudolph and Rudolph, Pursuit of Lakshmi, 302. Nav Nirman and Jayaprakash Narayan's mobilization of students in Bihar the same year are described as "exceptions rather than the norm." For more recent insight into student politics in India, see Craig Jeffrey, Timepass: Youth, Class and the Politics of Waiting in India (Stanford, 2010).

${ }^{65}$ Rudolph and Rudolph, Pursuit of Lakshmi, 291.

${ }^{66}$ See Nivedita Menon and Aditya Nigam, Power and Contestation: India since 1989 (Hyderabad, 2009). The Mandal Commission's recommendations for 27 percent reservations in educational institutions and public employment for "Other Backward Classes"-who constituted close to 60 percent of the population but occupied only 4 percent of government jobs - were fiercely contested both by India's Nehruvian elite and the Hindu right when implemented by Prime Minister VP Singh in 1990.

67 "Bhagat Singh and His Relevance Today!” AISA Official Website, posted 24 Mar. 2012 at www.aisa.in/1056 (last accessed 30 Mar. 2012; no longer online, pdf with author).

${ }^{68}$ Interview with Sucheta De and Vismay Basu (AISA), New Delhi, 2 Apr. 2012.

69 "Bhagat Singh and His Relevance Today!"

${ }^{70}$ Avtar Singh Sandhu (Paash), "Bhagat Singh ka Arth,” in Chaman Lal, ed., Vartaman ke Rubaru: Paash (New Delhi, 2000), 17-18.

${ }^{71}$ Interview with Sucheta De and Vismay Basu (AISA), New Delhi, 2 Feb. 2012.

${ }^{72}$ SK Pattnaik, Student Politics and Voting Behaviour: A Case Study of Jawaharlal Nehru University (New Delhi, 1982).

${ }^{73}$ See the detailed accounts in Praveen Donthi, "From Shadows to the Stars: The Defiant Politics of Rohith Vemula and the Ambedkar Students Association"; and Arundhati Roy, "My Seditious Heart," both in Caravan [magazine] (May 2016). See also Anupama Rao, "Editorial," Comparative Studies of South Asia, Africa and the Middle East 36, 1 (2016): 222-24.

74 “Interview: Kanhaiya Kumar on the 'Natural Alliance' of Ambedkarites and Leftists,” Wire (5 Mar. 2016), http://thewire.in/23863/most-natural-alliance-is-between-ambedkarites-and-leftists-kanhaiya-kumar/ (last accessed June 2016).

${ }^{75}$ See the group's Facebook page, https://www.facebook.com/Bhagat-Singh-Ambedkar-StudentsOrganisation-1150890268288524/ (last accessed June 2016). 
${ }^{76}$ See “Ambedkarite vs Left Debate: a Bahujan Perspective," Ambedkar Reading Group Blog, posted 31 May

2016, https://argdu.wordpress.com/2016/05/31/the-ambedkarite-left-debate-a-bahuian-perspective/ (accessed

February 2017).

${ }^{77}$ Interview with Anirban Bhattacharya and Reyazul Haque, Delhi, 10 June 2016.

${ }^{78}$ The SFI Delhi State was controversially dissolved by the CPI-M in July 2012 for being, among other things, "too political”; that is, not properly towing the party line. See Aditya Nigam's post, "CPI-M's 'July Crisis' and Challenges for Rebuilding the Left,” Kafila, posted 11 July 2012,

http://kafila.org/2012/07/11/cpims-july-crisis-and-challenges-for-rebuilding-the-left/ (last accessed Mar. 2016). See also the SFI Kerala site http://keralasfi.org/history (last accessed Mar. 2016).

${ }^{79}$ Interview with Roshan Kishore, New Delhi, 24 Apr. 2012.

${ }^{80}$ Sadda Haq, directed by Mandeep Benipal (OXL Films, 2013). The states were Punjab, Haryana, Delhi, Jammu and Kashmir, and Uttarkhand.

${ }^{81}$ On this period, see Joyce J. M. Pettigrew, The Sikhs of the Punjab: Unheard Voices of State and Guerrilla Violence (London, 1995).

82 “On Release Eve, Punjab Bans ‘Sadda Haq,"” Times of India, 5 Apr. 2013.

${ }^{83}$ For English press coverage, see Hartosh Singh Bal's essay, “The Shattered Dome,” Caravan [magazine] (May 2014); and Revati Laul, “The After-Life of Jarnail Singh Bhindranwale,” Yahoo News India, posted 2 June 2014, https://in.news.yahoo.com/the-after-life-of-jarnail-singh-bhindranwale-075231806.html (last accessed Mar. 2016). On the Delhi riots, see photographer Gauri Gill’s pamphlet “1984,” released in April 2013, http://www.gaurigill.com/books.html (last accessed Mar. 2016).

${ }^{84}$ On the "presumed masculinity" of the Sikh subject, see Brian K Axel, The Nation's Tortured Body: Violence, Representation, and the Formation of a Sikh "Diaspora” (Durham, 2001); and Veena Das, "Crisis and Representation: Rumor and the Circulation of Hate," in Michael S. Roth and Charles G. Salas, eds., Disturbing Remains: Memory, History, and Crisis in the Twentieth Century (Issues \& Debates) (Los Angeles, 2001), 37-62.

${ }^{85}$ I am grateful to Virinder Kalra for discussion on the significance of the baghi. See: "Baghi $\mid$ Jazzy B | Fully Music Video | Sadda Haq," posted by user “Jazzy B” on YouTube, 24 Mar. 2013, https://www.youtube.com/watch?v=Jh-VH5TdJcg (last accessed Mar. 2016).

${ }^{86}$ Pritam Singh and Navtej K Purewal, “The Resurgence of Bhindranwale's Image in Contemporary Punjab," Contemporary South Asia 21, 2 (2013): 133-47. 
${ }^{87}$ Bittu is the grandson of assassinated Chief Minister Beant Singh. "Jazzy B in Yet Another Row," Times of India, 4 Apr. 2013.

${ }^{88}$ Axel, Nation's Tortured Body; "Pro-Khalistani Group Distributes "Sadda Haq" in Canada," Indian Express, 12 Apr. 2013.

${ }^{89}$ Louis E. Fenech charts a similar process with famous gunman Udham Singh, whose "individual identity was ... clearly subsumed and reshaped by the discourse of martyrdom"; "Contested Nationalisms; Negotiated Terrains: The Way Sikhs Remember Udham Singh 'Shahid' (1899-1940),” Modern Asian Studies 36, 4 (2002): $827-70,855$.

${ }^{90}$ On authorization as a function of tradition, see David Scott, "On the Very Idea of a Radical Black Tradition,” Small Axe 17, 1 (2013): 1-6; and Talal Asad, “Anthropology and the Analysis of Ideology,” Man 14, 4 (1979): 607-27.

${ }^{91}$ Joyce Pettigrew suggests, "There has never been in Punjab a period of peace long enough to allow a forgetfulness of the contingent”; Robber Noblemen: A Study of the Political System of the Sikh Jats (London, 1975), 32. On the trope of "frontier" identity in Punjabi literature, see I. D. Gaur, Martyr as Bridegroom: A Folk Representation of Bhagat Singh (London, 2008), 24-25.

${ }^{92}$ The most direct treatment remains the documentary In Memory of Friends, directed by Anand Patwardhan (Independent Release, 1990).

${ }^{93}$ This alignment with a history of honorable death was evident in the immediate wake of his execution; see Ramaswamy, Goddess.

${ }^{94}$ Gaur, Martyr, 165.

${ }^{95}$ Fenech, "Contested Nationalisms," 8. See also Fenech, Martyrdom.

${ }^{96}$ Gaur, Martyr, 26.

${ }^{97}$ Cynthia Keppley Mahmood, Fighting for Faith and Nation: Dialogues with Sikh Militants (Philadelphia, 1996), esp. ch. 8. See also Bal, "Shattered Dome."

${ }^{98}$ National newspapers carried abridged versions of the letter in July 1990, with only the Chandigarh-daily Tribune publishing the full version on 28 July after one of its correspondents received threats of violence. See the Press Council of India's report on militancy in Punjab and Kashmir: Crisis and Credibility: Lancer Paper 4 (New Delhi, 1991), esp. 22.

99 "Text of Bhai Sukha and Bhai Jinda's Letter to the President of India," Panthic.org, http://panthic.org/articles/5155 (last accessed Mar. 2016). 
${ }^{100}$ Ibid. Sukha Singh and Mehtab Singh were eighteenth-century figures revered for killing the pro-Mughal kotwal of Amritsar, Massa Rangar, loathed for his disregard for Sikh customs. Wazida refers to the infamous Nawab of Sirhind at the time of Guru Gobind Singh, while Lakhpat Rai was the diwan in Mughal Lahore notorious for massacring Sikhs in the 1740s. Julio Rebeiro was director general of the Punjab police during Sukha and Jinda's time and responsible for brutal crackdowns on Sikh militants. Dawyer is likely a misspelling of O’Dwyer, the Punjab lieutenant-governor assassinated by Udham Singh, but it also echoes Brigadier-General Reginald Dyer, who ordered the shooting at Jallianwala Bagh and died of natural causes in England in 1927.

${ }^{101}$ Bhagat Singh “On the Slogan of Long Live Revolution,” in Shiv Varma, ed., Selected Writings of Shaheed Bhagat Singh (Kanpur, 1996).

102 "Jinda, Sukha to Hang," Times of India, 22 Oct. 1989.

${ }^{103}$ See "Videos" on Jazzy B Official Website, http://www.jazzyb.com/ (last accessed Mar. 2016).

${ }^{104}$ Nicola Mooney, "Dancing in Diasporic Space: Bhangra, Caste, and Gender among Jat Sikhs,” in Michael Hawley, ed., Sikh Diaspora: Theory, Agency, and Experience (Leiden, 2013), 279-318, 310.

${ }^{105}$ Ibid. On bhangra's global career, see Virinder S Kalra, "Vilayeti Rhythms," Theory, Culture \& Society 17, 3 (2000): 80-102. For Jazzy B's context in contemporary Punjab, see Isha Singh Sawhney, "Swagga like Us: The Unstoppable Boys of Punjabi Pop,” Caravan [magazine] (Nov. 2013).

${ }^{106}$ See "Main Fan Bhagat Singh Da_Diljit Dosanjh—Bikkar Bai Sentimental Official Full Video," posted by user "Sony Music India" on YouTube, 22 Mar. 2013, https://www.youtube.com/watch?v=gDE0SLOw-OI (last accessed Mar. 2016). Yo Yo Honey Singh was featured on Nishawn Bhullar's album The Folkstar (2010), contributing to the song "Bhagat Singh." When Honey Singh has been criticized in the press for references to sexual violence in his songs, he often refers to his admiration for Bhagat Singh, as if to prove his credibility. For instance: "Honey Singh: Do You Know I’ve Sung a Song about Bhagat Singh?” Parda Phhash, 2 Jan. 2013, http://www.pardaphash.com/new/news/honey-singh-do-you-know-ive-sung-a-song-about-bhagatsingh/54506.html (last accessed Mar. 2016).

${ }^{107} \mathrm{Zulm}$ is conventionally understood as "oppression directed against an entire people and so intense it has to be resisted." See Joyce Pettigrew, Sikhs of the Punjab, 10.

${ }^{108}$ Arundhati Roy, ed., 13 December: A Reader (Delhi, 2006).

${ }^{109}$ Firdous Syed, “Afzal Guru’s Hanging Has Widened Gulf between Delhi and Kashmir,” DNA India, 20 Feb. 2013.

110 “Kashmiri Students Protest in Delhi Against Guru’s Hanging,” Kashmir Media Service, 23 Feb. 2012, 
http://www.kmsnews.org/news/2013/02/23/students-protest-in-new-delhi-against-guru's-hanging.html (last accessed Apr. 2016).

111 “Gun an Option for Kashmir Solution: Syed Ali Geelani,” Times of India, 12 Nov. 2013. 